\title{
Genetic and Molecular Mechanisms Conferring Heat Stress Tolerance in Tomato Plants
}

\author{
Ken Hoshikawa ${ }^{1,2,3 *}$, Dung Pham ${ }^{4}$, Hiroshi Ezura ${ }^{2}$, Roland Schafleitner ${ }^{3}$ and \\ Kazuo Nakashima ${ }^{1 *}$ \\ 1 Japan International Research Center for Agricultural Sciences, Tsukuba, Japan, ${ }^{2}$ Tsukuba Plant Innovation Research \\ Center, University of Tsukuba, Tsukuba, Japan, ${ }^{3}$ Vegetable Diversity and Improvement, World Vegetable Center, Tainan, \\ Taiwan, ${ }^{4}$ Faculty of Biotechnology, Vietnam National University of Agriculture, Hanoi, Vietnam
}

Climate change is a major threat to global food security. Changes in climate can directly impact food systems by reducing the production and genetic diversity of crops and their wild relatives, thereby restricting future options for breeding improved varieties and reducing the ability to adapt crops to future challenges. The global surface temperature is predicted to rise by an average of $0.3^{\circ} \mathrm{C}$ during the next decade, and the Paris Agreement (Paris Climate Accords) aims to limit global warming to below an average of $2^{\circ} \mathrm{C}$, preferably to $1.5^{\circ} \mathrm{C}$ compared to pre-industrial levels. Even if the goal of the Paris Agreement can be met, the predicted rise in temperatures will increase the likelihood of extreme weather events, including heatwaves, making heat stress (HS) a major global abiotic stress factor for many crops. HS can have adverse effects on plant morphology, physiology, and biochemistry during all stages of vegetative and reproductive development. In fruiting vegetables, even moderate HS reduces fruit set and yields, and high temperatures may result in poor fruit quality. In this review, we emphasize the effects of abiotic stress, especially at high temperatures, on crop plants, such as tomatoes, touching upon key processes determining plant growth and yield. Specifically, we investigated the molecular mechanisms involved in HS tolerance and the challenges of developing heat-tolerant tomato varieties. Finally, we discuss a strategy for effectively improving the heat tolerance of vegetable crops.

\section{Keywords: climate change, abiotic stress, heat stress, molecular mechanism, vegetable, tomato}

\section{INTRODUCTION}

Climate change, specifically a rise in ambient temperatures, is predicted to significantly affect plant growth and development, resulting in a devastating reduction in crop productivity, causing severe famine and limiting global food security (FAO-STAT, http://faostat.fao.org; Verisk Maplecroft, https://www.maplecroft.com; (Bita and Gerats, 2013). According to the report of the Intergovernmental Panel on Climate Change (IPCC), the accumulation of atmospheric concentrations of greenhouse gases (GHGs), such as $\mathrm{CO}_{2}, \mathrm{~N}_{2} \mathrm{O}$, and $\mathrm{CH}_{4}$, which can absorb infrared radiation reflected from the Earth's surface, was caused by the combustion of fossil energy sources and the associated GHG emissions. Changes in the atmospheric concentrations of GHGs suggested an alteration in the energy balance of our climate, causing the global surface temperature to increase by $0.3^{\circ} \mathrm{C}$ during the next decade and is expected to reach $1.8-4.0^{\circ} \mathrm{C}$ by 2100 
(Jones et al., 1999; Stocker et al., 2013). During the Conference of Parties 21 (COP21) conference in Paris in 2015, governments of most countries agreed to reduce the use of fossil fuels with the ambition of a complete waiver at the end of the century, thereby attempting to limit global warming to below a $2^{\circ} \mathrm{C}$ increase, preferably to $1.5^{\circ} \mathrm{C}$ compared to pre-industrial levels. However, even if the goal of the Paris Agreement is achieved, the initiated threat of heat stress (HS) is not addressed in agriculture as HS is a major global abiotic stress factor for many crops. Due to the increased frequency of extreme weather events, including heatwaves, HS remains a threat to global agricultural production and food security. With $75 \%$ of the world's poor living in rural areas and nearly $50 \%$ of people in underdeveloped countries relying on agriculture for income, these stakeholders are likely to experience the most serious effects of climate change. In addition, a population rise to 9 billion by the year 2050 and rising food demand in rapidly growing economies, such as China and India, will require a $70 \%$ increase in food production to fulfill future needs. Increasing food production while climate change is expected to lead to tremendous crop losses is a challenge that can only be solved by more sustainable agricultural production systems using crop varieties that are more tolerant to abiotic stresses than the presently used varieties. Insights into the mechanisms allowing plants to grow and yield under stressful conditions are key to breeding more stress-tolerant varieties.

Plants, as sessile organisms, are frequently affected by adverse environmental factors, such as drought and temperatures that are hotter or colder than their optimal range. Therefore, plants adapt to stressful conditions to a certain extent. In general, when the ambient temperature is $10-15^{\circ} \mathrm{C}$ higher than the optimum temperature range for plant cultivation, such conditions are defined as HS (Wahid et al., 2007). HS can cause negative effects on plant morphology, development, physiology, biochemistry, and molecular pathways at all vegetative and reproductive stages. Anther and pollen development at anthesis are very sensitive to temperature fluctuations, causing failure of reproduction and fertilization processes (Warrag and Hall, 1984; Monterroso and Wien, 1990; Peet et al., 1998; Erickson and Markhart, 2002). Consequently, significant adverse effects on reproduction and fertilization processes cause a reduction in fruit set and lower quality fruit and vegetable yields (Bita and Gerats, 2013; Hasanuzzaman et al., 2013). Significant efforts by researchers and breeders are dedicated to overcoming the negative effects of HS. Plants respond to temperature fluctuations and induce shortterm stress avoidance or acclimatization mechanisms, including leaf re-orientation to create space, transpiration acceleration for cooling, and alteration of membrane lipid composition (Wahid et al., 2007). At the cellular level, plants adapt to HS through various mechanisms, such as transcription, post-transcription,

\footnotetext{
Abbreviations: ABA, abscisic acid; AGL6, AGAMOUS-LIKE 6; AP3, APETALA3; BRs, Brassinosteroids; DREBs, dehydration-responsive element-binding; ER, endoplasmic reticulum; ET, ethylene; GAs, gibberellins; GHG, greenhouse gas; HS, heat stress; HsfA1, heat stress transcription factor A1; HSFs, heat stress transcription factors; HSPs, heat shock proteins; JA, jasmonate; PCD, programmed cell death; PI, PISTILLATA; ROS, reactive oxygen species; $s H S P s$, small heat shock proteins; SA, salicylic acid; TM6, TOMATO MADS BOX GENE6; TSS, total soluble solids content; UPR, unfolded protein response.
}

translation, post-translation, and regulation, at different levels, for example, in calcium, phytohormone, sugar, and lipid signaling, and in primary and secondary metabolism (Bita and Gerats, 2013). Moreover, thermotolerance is regulated by a complex transcriptome network of distinct and interconnected pathways to maintain protein homeostasis and minimize cellular damage (Keller and Simm, 2018).

Tomato (Solanum lycopersicum), as a fruit vegetable crop, is of immense importance to the global economy and food culture and is a popular vegetable that is produced worldwide. China is the world's largest tomato producer, followed by India and Turkey (FAOSTAT, http://www.fao.org/). Tomatoes are rich in nutrients, such as vitamin $\mathrm{C}, \beta$-carotene, and lycopene, which have positive effects on human health (Bergougnoux, 2014). Several institutions have developed tomato genetic resources for researchers and breeders studying heat tolerance and many traits of importance. The Solanaceae Genomics Network (SGN, http://solgenomics.net/) is an online genomic database that provides essential information for researchers. In the USA, the Tomato Genetics Resource Center (TGRC) at the University of California, Davis (http://tgrc.ucdavis.edu/) is an excellent source of diverse germplasm, wild species, and core collections. In Taiwan, the World Vegetable Center (http://seed.worldveg.org) curates 8,835 tomato accessions, of which 6,676 are available on request. In Japan, genetic resources of tomato plants have been collected by the National Agriculture and Food Research Organization (NARO) Genebank (https://www.gene.affrc.go.jp) and the National BioResource Project (NBRP)-Tomato (https:// tomato.nbrp.jp). In the NBRP-Tomato, over 10,000 Micro-Tom mutants, created by ethyl methanesulfonate (EMS) mutagenesis and gamma-ray irradiation, have been collected (Watanabe et al., 2007; Matsukura et al., 2008). Micro-Tom is becoming a model plant for studying both fruit production and tolerance to various abiotic and biotic stresses (Ezura, 2016). Researchers can access information regarding this mutagenic line through the online database TOMATOMA (http://tomatoma.nbrp.jp/index. jsp) (Saito et al., 2011; Shikata et al., 2016).

Tomato plants are often exposed to temperature fluctuations during cultivation, and HS significantly affects reproduction and fertilization, leading to crop failure and a decrease in the quantity and quality of harvested fruit (Prasad et al., 1999; Sato et al., 2000). The morphological and physiological changes in response to HS in tomatoes are different among entries or accessions, at different development stages, and with varying HS exposure periods. These changes are not only detected in vegetative organs, such as leaves (Zhou et al., 2017), but also in reproductive organs, such as flowers and gametophytes (Firon et al., 2006). Firon et al. (2006) reported that the relationship between pollen viability and fruit set in tomatoes was detected under HS conditions. Pan et al. (2019) reported that the alteration of flower structure, such as stigma exertion, was associated with jasmonate (JA) signaling and other plant hormone pathways, resulting in low fruit setting.

We reviewed the effects of high temperatures on tomato plants to address key processes determining plant growth and yield. This review focuses on the molecular mechanisms, the morphological and physiological mechanisms contributing to HS tolerance, and the challenges in developing heat-tolerant vegetable varieties. 


\section{MORPHOLOGICAL AND PHYSIOLOGICAL PROCESSES IN TOMATO PLANTS UNDER HS}

Plant response to HS varies according to developmental stage, species, genotype, and the timing of HS events (Firon et al., 2006; Barnabás et al., 2008; Sakata and Higashitani, 2008; Shanmugam et al., 2013; Sharma et al., 2014) (Figure 1). HS resistance is genetically diverse (Ayenan et al., 2019; Bineau et al., 2021). Since their physiological mechanisms are equally diverse, we will first explain the physiological mechanisms and then explain the genetic diversity of HS resistance for breeding. Under HS, plants exhibit many physiological responses, such as abscission and senescence of leaves, growth inhibition of the shoots and roots, and fruit damage, resulting in a substantial decrease in plant productivity (Figure 1) (Vollenweider and GünthardtGoerg, 2005). Extreme HS affects performance and crop quality characteristics. The productivity decrease under HS has been attributed to decreased assimilatory capacity associated with reduced photosynthesis caused by altered membrane stability, enhanced maintenance respiration costs, and a reduction in radiation use efficiency (Zhang et al., 2006; Reynolds et al., 2007; Hasanuzzaman et al., 2013). At the beginning of cultivation, reduced germination percentage, reduced plant emergence, abnormal seedlings, poor seedling vigor, and reduced radicle and plumule growth of germinated seedlings are major impacts of HS and have been documented in various cultivated plant species (Toh et al., 2008; Kumar et al., 2011; Piramila et al., 2012). When tomato plants are cultivated at $42^{\circ} \mathrm{C}$, they sustain severe damage at various stages of development, including seed germination, vegetative and reproductive growth, and fruit setting (Wahid et al., 2007).

In general, the intensity, duration, and rate of temperature alteration during the growth and development of tomatoes are the main factors for evaluating the influence of HS (Wahid et al., 2007). During primary synthesis and respiration processes, leaves retain stomata machinery, which regulates gas exchange and water vapor between the atmosphere and the intracellular space, resulting in an adaptation to changes in the cultivation environment (Negi et al., 2008). An increase in $\mathrm{CO}_{2}$ concentration inhibits the opening and closing of stomata on stomatal apertures (Medlyn et al., 2001; Hashimoto et al., 2006; Ainsworth and Rogers, 2007; Ji et al., 2015). The temperature on the leaf surface influences stomatal density and status; for example, the opening and closing of stomata form a complex network that controls gas exchange and water vapor to adapt to abiotic stresses (Valladares and Pearcy, 1997; ReynoldsHenne et al., 2010). Tomato plants of the cultivar Campbell 28, when heat treated $\left(45^{\circ} \mathrm{C}\right)$, had increased stomatal conductance compared to plants under control conditions $\left(25^{\circ} \mathrm{C}\right)$, indicating that stomatal closure did not control the reduction in $\mathrm{CO}_{2}$ (Camejo et al. 2005). Increases in stomatal conductance have been reported in plants exposed to HS (Radin et al., 1994; Zhou et al., 2015), while others have found that stomatal conductance is significantly reduced (Weston and Bauerle, 2007; Neill et al., 2008; Lahr et al., 2015; von Caemmerer and Evans, 2015). It is known that salicylic acid (SA) auxin, cytokinin, ethylene (ET),

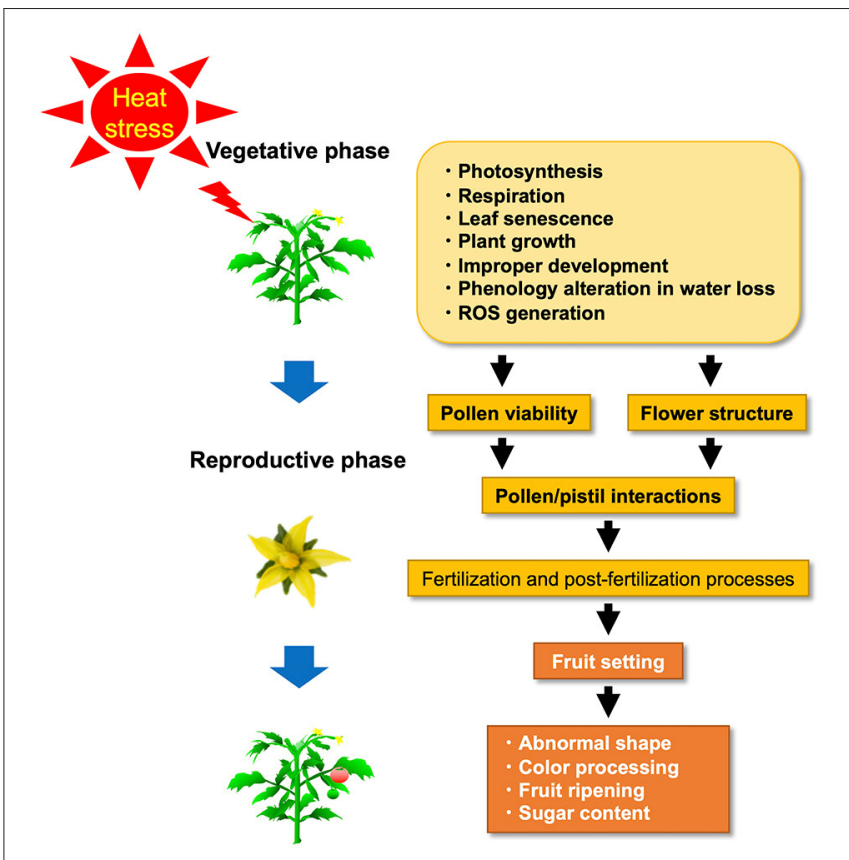

FIGURE 1 | Adverse effects of heat stress (HS) on the vegetative and reproductive phase in tomatoes.

brassinosteroids (BRs), and JA regulate stomatal function, while abscisic acid (ABA) is not involved (Miura and Tada, 2014).

Heat stress adversely affects respiration and photosynthesis, leading to a shortening of the life cycle and a significant decrease in plant productivity (Barnabás et al., 2008). At the beginning of HS, the response is expressed through structural alterations in chloroplast protein complexes and reduced enzyme activity (Bita and Gerats, 2013), followed by damage to the cell membrane and the organization of microtubules. The cytoskeleton can also be damaged, because HS negatively influences membrane permeability, causing alterations in cell differentiation, elongation, and expansion (Smertenko et al., 1997; Potters et al., 2009). The retention of cellular membrane function is essential for sustainable and stable photosynthetic and respiratory continuity under HS (Chen et al., 2012). Some researchers have reported that swelling and aberration of grana stacks occur on photosynthetic membranes, resulting in associated changes in energy allocation to photosystems and ion leakage from leaf cells (Wahid and Shabbir, 2005; Allakhverdiev et al., 2008).

The negative effect of HS on chlorophyll and the photosynthetic apparatus results in the overproduction of reactive oxygen species (ROS), which are involved in responses to biotic and abiotic stresses (Vara Prasad et al., 2000; Shi et al., 2015). HS reduces photosynthesis and respiratory activity by increasing chlorophyllase activity and reducing the number of photosynthetic pigments (Todorov et al., 2003; Sharkey and Zhang, 2010). An increase in the concentration of ROS was not only associated with programmed cell death (PCD) but also with various metabolic reactions, such as DNA damage, 
enzyme activity impairment, lipid peroxidation in cellular membranes, carbohydrate oxidation, protein denaturation, and the breakdown of pigments (Bose et al., 2014). Hydrogen peroxide $\left(\mathrm{H}_{2} \mathrm{O}_{2}\right)$ is one of the main ROS components produced by plants and fruit tissues under control and HS conditions. In plants, $\mathrm{H}_{2} \mathrm{O}_{2}$ functions not only as an essential signal that upregulates antioxidant enzyme activities but also mediates ABA-induced stomatal closure to promote stress tolerance ( $\mathrm{Hu}$ et al., 2005). In addition, hydrogen peroxide accumulates and enhances the thermotolerance of plants when they are treated with low concentrations of SA (Horváth et al., 2007).

Ionic leakage is related to ROS accumulation under stress conditions (Demidchik et al., 2014). Drought stress has been found to result in increased ion leakage in drought-sensitive tomato entry (Thirumalaikumar et al., 2018). There are two popular methods for measuring ion leakage to estimate the heat tolerance in plants: (i) the common ion leakage measurement based on the total electrical conductivity released before and after heating and (ii) the estimation of basal heat tolerance based on the cell suspension or the gradual (linear) heating of plant segments (Ilík et al., 2018). Total ionic leakage is among the most important factors in determining plant responses to abiotic and biotic stresses, as it is associated with stress-induced injury related to PCD in plants (Zhu, 2016).

Antioxidant defense plays an important role in the response of tomato plants to various abiotic stresses. HS causes serious damage to antioxidant enzymes function; therefore, tomato plants are required to regulate SA and activate other biochemical pathways to enhance heat tolerance (Jahan et al., 2019). ROS acts as a transduction signal of heat tolerance; hence, superoxide dismutase (SOD) and ascorbic acid peroxidase (APX) are involved in the antioxidant defense mechanism in tomato plants in response to the negative effects of high temperature (Zhou et al., 2019) (Table 1).

It has been reported that leaf senescence is accelerated by HS during cultivation. Leaf senescence genes are correlated with PCD and are regulated by multiple levels of chromatin structure, transcription, post-transcription, translation, and posttranslation (Woo et al., 2013) (Table 1). Leaf senescence genes are also interconnected with other genes responsible for responding to abiotic and biotic stresses. Senescence upregulated 3 (SENU3) is a ubiquitous cysteine protease (CP) that is associated with vacuolar senescence in pepper (Drake et al., 1996; Xiao et al., 2014). Another gene involved in leaf senescence is the rubisco large subunit $(R b c L)$, which is in the chloroplast DNA and functions as a key enzyme for carbon assimilation and fixation (Enyedi and Pell, 1992; Wang et al., 2015). RbcL expression is regulated in response to environmental changes ( $\mathrm{Xu}$ and Tabita, 1996).

\section{MOLECULAR MECHANISM FOR THERMOTOLERANCE IN TOMATOES}

Plants respond to elevated temperatures and ensure survival through various mechanisms, such as transcription, translation, and regulation of calcium, phytohormone, sugar, and lipid signaling, and of primary and secondary metabolism (Bita and Gerats, 2013). Molecular pathway-related thermotolerance has been identified in Arabidopsis, tomato, and other species (Qu et al., 2013; Ohama et al., 2017) (Table 1). The complex transcriptional pathways were reviewed by Ohama et al. (2017). The HS factor (Hsf) is a transcription factor (TF) associated with HS (Figure 2). Many eukaryotes have one to three Hsfs, but plants have over 20, which are classified as A, B, and C. Class A Hsfs are transcriptional activators. Ikeda et al. (2011) found that class B Hsfs of Arabidopsis, HsfB1, and $\mathrm{HsfB} 2 \mathrm{~b}$, are transcriptional repressors that negatively express heat-induced Hsfs (HsfA2, HsfA7a, HsfB1, and HsfB2b) and a few heat shock protein genes. Yoshida et al. (2011) analyzed the dehydration-responsive element-binding protein 2A (DREB2A) promoter and discovered a heat shock element that functions as a cis-acting element in the expression of HS responsiveness of DREB2A. They generated multiple mutants and found that HS-responsive expression of DREB2A was abolished in the $h s f a 1 a / b / d$ triple and $h s f a 1 a / b / d / e$ quadruple mutants. They further showed that HsfAla, HsfA1b, and HsfA1d function as major positive regulators of HS-responsive gene expression and that four HsfA1-type proteins are important for gene expression during normal plant growth. Therefore, HsfA1 is the master regulator of the plant's HS response (HSR). Due to HS, HsfA1 causes a transcription cascade composed of many TFs. Higashi et al. (2013) reported HsfA1d, a protein identified through full-length cDNA Over-eXpressing gene (FOX) hunting, using Thellungiella salsuginea, a species closely related to Arabidopsis. cDNAs improve heat tolerance by regulating HS-responsive gene expression. Ohama et al. (2016) reported that the central region of HsfAld, one of several Arabidopsis HsfA1, is an important regulatory domain that suppresses HsfA1d transactivation activity by interacting with heat shock protein70 (HSP70) and HSP90. They designated this region as the temperature-dependent repression (TDR) domain. Overexpression of constitutively active HsfA1d, which lacks the TDR domain, induced the expression of heat shock proteins in the absence of HS, thereby conferring strong thermal stability to the overexpressors. In this manner, HsfAs control many HSrelated factors, including DREB2, and the understanding of their temperature-controlled mechanism is also progressing.

Four types of HsfA1 were isolated in Arabidopsis (HsfA1 a, b, c, and d) (Liu et al., 2011), while four different types were identified in tomatoes (HsfA1, a, b, c, e) (El-Shershaby et al., 2019). In HsfA1 families, HsfAla seems to have a unique function as a master regulator for acquired thermotolerance, and it cannot be replaced by other genes (Mishra et al., 2002; Scharf et al., 2012). Other members of the HsfAlfamilies are induced in specific tissues and stages of the HSR (El-Shershaby et al., 2019). SlHsfAla function was confirmed by the heat tolerance levels at the incorporation of two HsfA1 transgene cassettes, resulting in a 10- to 15 -fold increase in the overexpression line that contained a single HsfAla transgene cassette and co-suppression line with two cassettes of transgene tandem inverted repeat inserted, respectively (Baniwal et al., 2004). Moreover, with a low abundance of mRNA, HsfAla was constitutively expressed (Fragkostefanakis et al., 2016). HsfA1d increases heat tolerance 
TABLE 1 | Key genes related to heat stress (HS) mechanisms are introduced in this review.

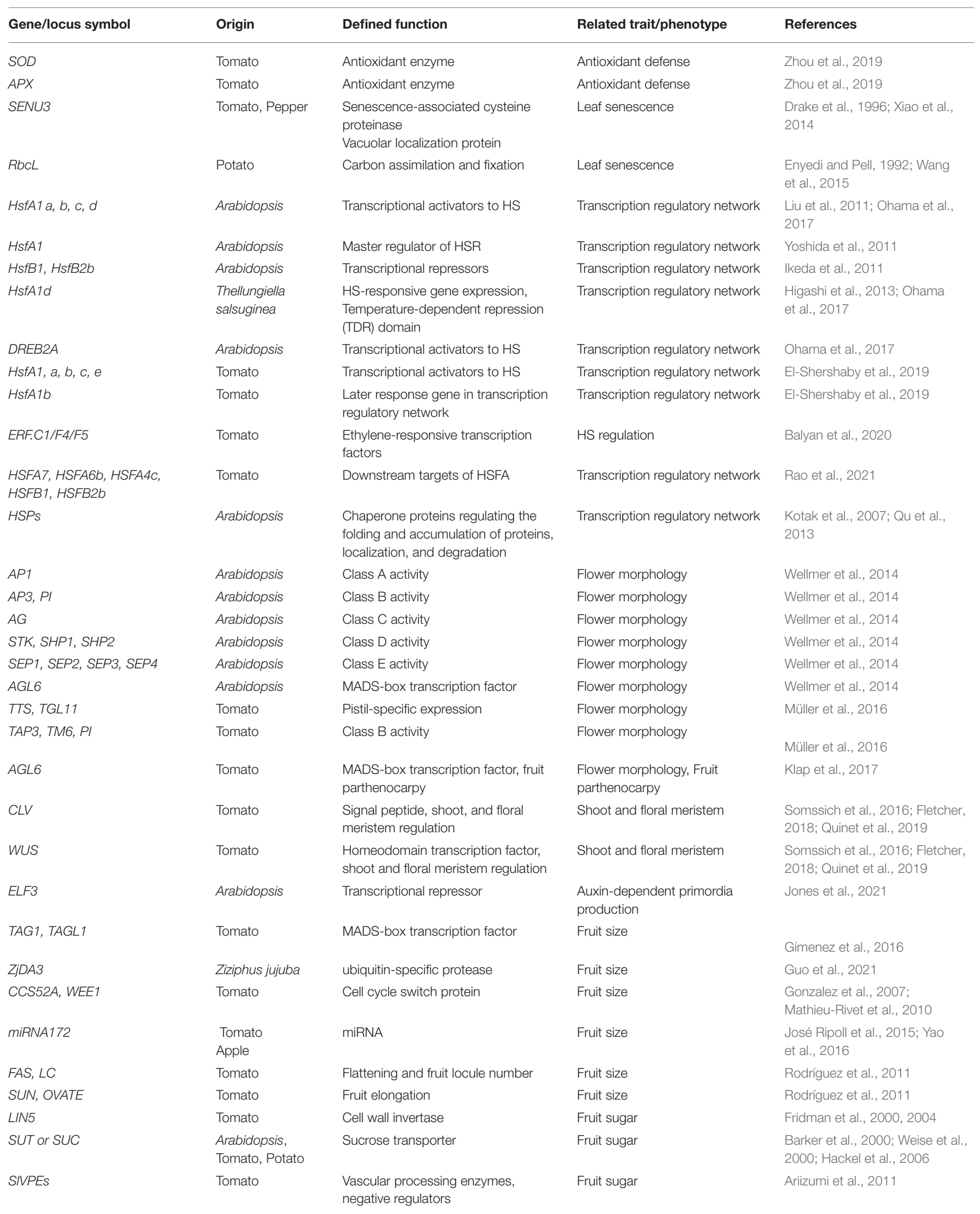




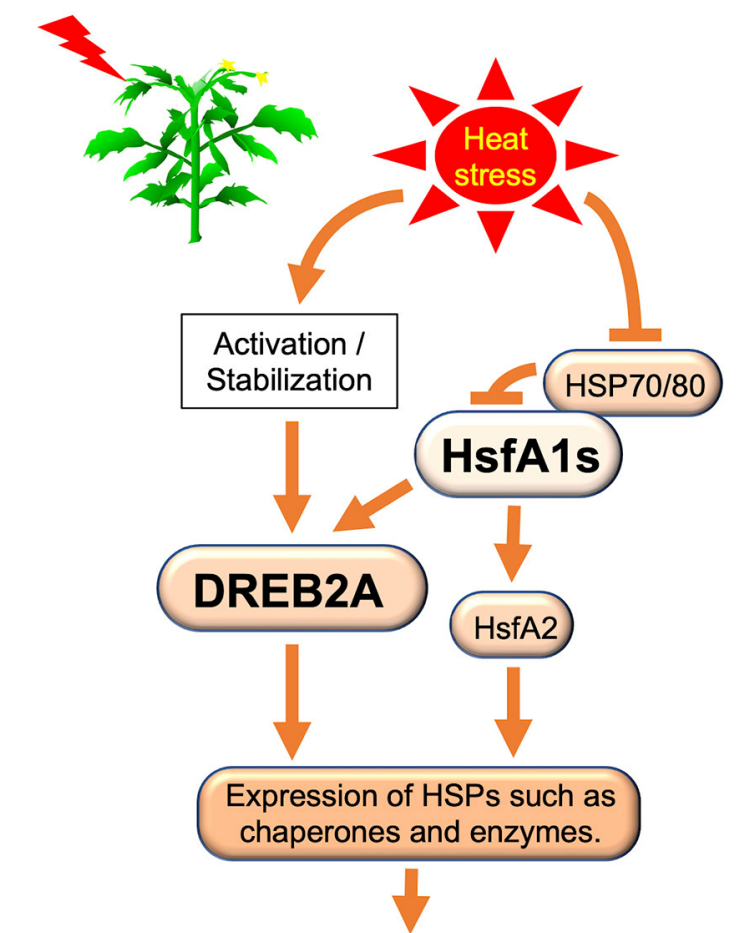

\section{Acquisition of thermotolerance}

FIGURE 2 | Schematic transcriptional regulatory network in plants examined in this review. in soybean (Ohama et al., 2017). HsfAlb is a member of the HsfA1 subfamily, which is induced under HS conditions (above $35^{\circ} \mathrm{C}$ ). Under $\mathrm{HS}$ conditions, HsfAla was stably expressed, whereas HsfAlb showed high variation in gene expression in mature green fruits and young leaves (El-Shershaby et al., 2019). In addition, the HsfA1b function is mainly controlled at the transcriptional level by HsfAl members (Fragkostefanakis et al., 2016). HsfA1b was strongly expressed in fruits, and high fluctuation was observed among different tissues. The results suggested that HsfAlb is a later response gene under HS (El-Shershaby et al., 2019). Several tolerant genes, such as HsfA2, HsfA3, induced-heat shock protein HSPs, ET-responsive transcriptional coactivator multiprotein bridging factor ER24 (LeMBF1), cytosolic ascorbate peroxidase 3 (SlAPX3) (a ROS scavenger), and calcium-dependent protein kinase 2 (CDPK2), were isolated from the anthers (Frank et al., 2009; Zinn et al., 2010). Recently, Balyan et al. (2020) have reported that there is redundancy in cultivar-specific HS regulation compared to transcriptomes between resistant (CLN1621L) and susceptible (CA4) cultivars. Enzymes and proteins related to plant defense and abiotic stress are antagonistically expressed. This study suggested that three ET-responsive TFs (ERF.C1/F4/F5), as several novel HS-resistant genes, improved tomato HS resistance. Rao et al. (2021) reported HSFA7, HSFA6b, HSFA4c, HSFB1, and HSFB2b as new downstream targets of HSFA1a in tomatoes during $\mathbf{H S}$.

Heat shock proteins are regulated by HSFs, which control protein quality (Scharf et al., 2012). HSPs are crucial chaperone proteins that are induced during HSR. The HSP family includes a number of small HSPs (sHSPs) and sub-family proteins HSP60, HSP70, HSP90, and HSP100 (Kotak et al., 2007; Qu et al., 2013). The Hsp21 gene is related to chloroplasts and photosynthesis (Neta-Sharir et al., 2005; Zhong et al., 2013), whereas HSP101 is among tolerant genes, such as stable Rubisco isoforms and other genes identified from anther profiling (Zinn et al., 2010). In HS, HSPs play important roles in the regulation of protein quality through protein denaturation. HSP21 is a small HSP in Arabidopsis, necessary for chloroplast development to protect photosynthesis (Zhong et al., 2013). HSP101 functions as a chaperone in protein degradation (Wang et al., 2004). Despite the important role it plays in sHSP thermotolerance, the underlying mechanisms are not known (Ohama et al., 2017).

Studying the expression levels of TFs and HSPs in tomatoes under HS will help understand the molecular mechanisms of mutant response to high temperatures.

\section{INFLUENCE OF HS ON THE REPRODUCTIVE ORGANS AND REPRODUCTIVE PHASE IN TOMATO PLANTS}

The reproductive stage of the plant and the reproductive organs are highly sensitive to HS, which is a major yield-reducing factor. Various reproductive phases, especially stages including meiosis in both male and female organs, pollen germination, pollen tube growth, pollen/pistil interactions, fertilization and postfertilization processes, formation of the endosperm, and embryo development, are highly sensitive to HS (Warrag and Hall, 1984; Monterroso and Wien, 1990; Peet et al., 1998; Erickson and Markhart, 2002).

Tomato is an autogamous species with a flower structure that is compatible with self-pollination; the anther cones (stamens) cover the style (stigma or pistil). The position and maturity of the male (anther cone) and female (style) organs are markedly affected by various abiotic stresses, including HS during bud development, causing stigma (style) exertion in tomato flowers (Figure 1) (Saeed et al., 2007; Yan et al., 2009; Pan et al., 2019). The effects of elevated temperatures on tomato flower morphology have been previously explored. The tomato stigma under HS is exerted, preventing self-pollination, and causing fruit-setting failure (Sato et al., 2006; Giorno et al., 2013). The exertion of tomato stigmas induced by HS is associated with various factors and pathways, such as JA signaling (Pan et al., 2019). Pan et al. (2019) reported that stigma exertion induced by HS was a result of the higher susceptibility of the stamen to HS as compared to the pistil and the differences in cell morphology in both. The discrepant coregulation of pectin, sugar, expansion, and cyclin in stamens and pistils determined cell shape and number by regulating cell expansion and division under HS. Auxin is required to regulate high temperature-induced growth 
inhibition in both stamens and pistils. JA plays a crucial role in protecting pistils against $\mathrm{HS}$, and the JA/JA receptor CORONATINE-INSENSITIVE 1 (COI1) signaling pathway is a key hub in stigma exertion. Müller et al. (2016) reported that concurrent reduction in pollen viability and pistil-like aberrant formation of anthers under HS is caused by altered localization of two pistil-specific gene products, TRANSMITTING TISSUE SPECIFIC (TTS) and TOMATO AGAMOUS LIKE11 (TGL11). This is accompanied by reduced expression of B-class genes, such as TOMATO APETALA3 (TAP3), TOMATO MADS BOX GENE6 (TM6), and PISTILLATA (PI) in the anthers (Kramer et al., 1998; Busi et al., 2003; de Martino et al., 2006). These reports showed that the downregulation of tomato B-class genes, induced by HS, contributes to anther deformation and reduced male fertility (Müller et al., 2016). Thus, flowers exposed to HS showed negative effects at various developmental stages, such as the inhibition of pollen release from anthers due to the failure of anther dehiscence, stigma exposure due to decreased stamen length, and pistil hyperplasia (Takeoka et al., 1991; Sato et al., 2002, 2006).

Maintaining floral morphological homeostasis is important because HS has adverse effects on flower morphology (Figure 3). The $A B C D E$ model genes include five classes, $\mathrm{A}, \mathrm{B}, \mathrm{C}, \mathrm{D}$, and $\mathrm{E}$ of floral development, which is encoded using MAD-box TFs (Rijpkema et al., 2010; Smaczniak et al., 2012), with the exception of class A gene APETALA2 (AP2) (Jofuku et al., 1994). In Arabidopsis, AP1 belongs to class A, AP 3 and $P I$ belong to class B, AGAMOUS (AG) belongs to class C, SEEDSTICK (STK), SHATTERPROOF1 (SHP1), and SHP2 belong to class D; and SEPALLATA1 (SEP1), SEP2, SEP3, and SEP4 belong to class $\mathrm{E}$ (Wellmer et al., 2014). In addition, the AGAMOUS-LIKE 6 (AGL6)-clade genes AGL6 and AGL13 play crucial roles in floral organ development, especially in ovule formation (Murai, 2013). In tomatoes, under mild HS, expression of the B-class PI, TAP3, and TM6 genes is reduced in the anthers (Müller et al., 2016). TM6 was partially silenced in response to temperature elevation, resulting in a reduced frequency of pistilloid anthers, pollen viability, and pollen quantity. Müller et al. (2016) suggested that downregulation of tomato B-class genes is related to anther deformations and reduces male fertility.

The AGL6-clade did not belong to the conventional $A B C D E$ model genes that regulate floral structure in plants but is likely to play a role in the ovary formation (Schauer et al., 2009). In tomato plants, the AGL6 mutant is related to fruit parthenocarpy (Klap et al., 2017). In addition, AGL6 also acts as a key regulator of the transition between the state of "ovary arrest" imposed toward anthesis and the fertilization-triggered fruit set (Klap et al., 2017). Silencing AGL6 results in green petals and fused sepals (Yu et al., 2017). The no apical meristem (NAM) protein is involved in the separation between sepal boundaries and flower whorls (Hendelman et al., 2013).

The reproductive phase of tomato plants starts from the first bud formation with the development of pollen that is more HS sensitive than female gametophytes and other vegetative organs (Bokszczanin et al., 2013). There are some reports on the pollen viability of tomato plants under HS, and flower buds at 7-15 days before anthesis were the most heat-sensitive of

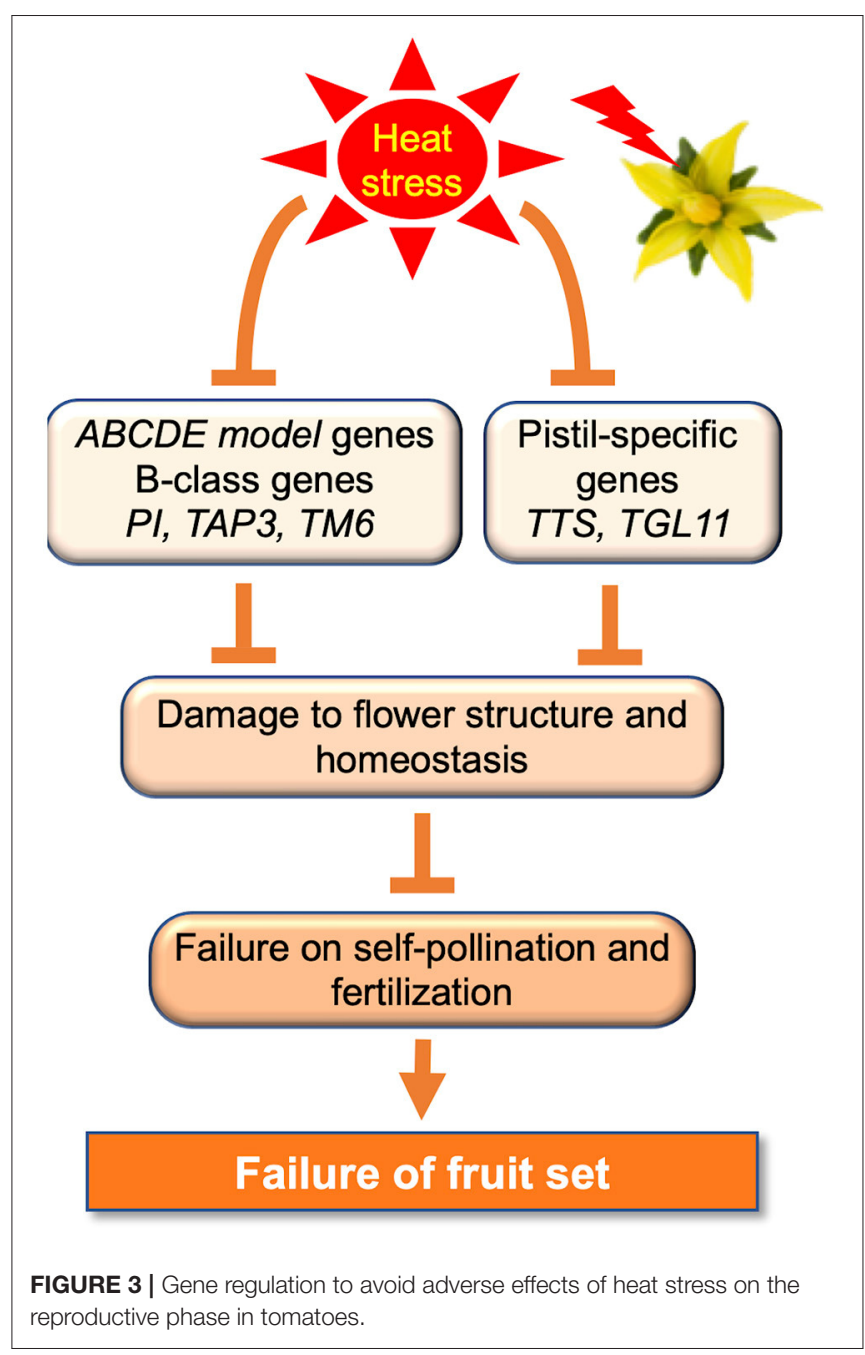

all developmental stages in tomato plants, as spindle formation in the meiosis phase is hypersensitive to HS (Sato et al., 2006). When pollen mother cells in the meiosis phase are damaged by HS, the quality and quantity of pollen grains are markedly reduced. As a matter of fact, tomatoes grown under $32 / 26^{\circ} \mathrm{C}$ day/night temperature could not release enough pollen, resulting in diminished fruit set (Sato et al., 2000, 2006). Additionally, pollen viability in tomato plants is controlled by a series of factors that are directly or indirectly involved in pollen thermotolerance. For example, secondary metabolites, such as flavonoids, accumulated in the mature pollen, might reduce the damage caused by ROS scavengers (Paupière et al., 2017). HS negatively affected both the early and late stages of pollen development. A complex network of metabolites and plant hormones is involved in the thermotolerance machinery of tomato pollen at different stages: (i) the early stage of pollen development involves the accumulation of unfolded protein response (UPR) in the endoplasmic reticulum (ER), cytoplasm, changes in histones, alternative splicing, ROS homeostasis, metabolic reprogramming, carbohydrates, plant hormones, and 
gibberellins (GAs); and (ii) the later stage of pollen development involves UPRs, ROS, amino acids (proline), carbohydrates, auxins, polyamines, flavonoids, and plant hormones (such as JAs, ETs, BRs, and ABA). Furthermore, compatible stigma and pollen also contributed to successful fruit and seed formation (Raja et al., 2019). Therefore, these factors should be considered when developing strategies to improve tomato fruit production under high-temperature conditions.

\section{NEGATIVE EFFECTS OF HS ON FRUIT DEVELOPMENT IN TOMATO PLANTS}

Heat stress suppressed tomato fruit development, resulting in abnormal fruit shapes and negative changes in color processing. HS not only decreases fruit setting but also influences fruit dehiscence and fruit morphology, resulting in dehydration, with wrinkled skin and dry, locular fruit cavities (Lin et al., 2011). Fruit quality is controlled by the cell number and cell size, sugar accumulation, traits related to fruit shape, colorimetry, total solids, texture, and flavor (Cheniclet et al., 2005; Chusreeaeom et al., 2014; Quinet et al., 2019). Fruit size is determined by the coordinated control of cell division and cell expansion. Fruit size is regulated by several molecular mechanisms, including hormonal regulation, the CLAVATAWUSCHEL (CLV-WUS) signaling pathway, the MADS-box family, the ubiquitin-proteasome pathway, quantitative trait loci (QTLs), microRNA, and endoreduplication (Yuste-Lisbona et al., 2020; Zhao et al., 2021). The CLV-WUS signaling pathway regulates the maintenance of stem cells in shoot and floral meristem, contributing to several agronomic traits, such as flower and fruit numbers (Fletcher, 2018; Quinet et al., 2019). The CLV-WUS feedback loop regulates meristem activity and floral meristem size during the initial phase of tomato fruit development, and it determines carpel number in flowers and, thus, seed locules in fruit during the later phases (Rodríguez-Leal et al., 2017). The signaling peptide CLV3 interacts directly with CLV1 or CLV2, which are leucine-rich repeat receptor kinases, and activates a signaling cascade that negatively regulates the activation of the stem cell-promoting TF WUS (Somssich et al., 2016). A loss-of-function mutation in any $C L V$ genes, such as natural mutations in fasciated (fas) and locule number ( $l c$ ), results in increased proliferation of stem cells and consequently the development of extra floral organs and larger fruits (Barrero et al., 2006; Xu et al., 2015; Fletcher, 2018). Jones et al. (2021) reported that high temperatures bypass CLV signaling and upregulate auxin through transcriptional repressor EARLY FLOWERING 3 (ELF3) in Arabidopsis; therefore, high temperatures and ELF3 regulate auxin-dependent primordia production. However, it is unclear how CLV2/CRN is involved in auxin-dependent flower initiation in Arabidopsis. Additionally, auxin and GA signaling pathways stimulate and directly activate tomato fruit sets (de Jong et al., 2009). TOMATO AGAMOUS1 (TAG1) and ARLEQUIN/TOMATO AGAMOUS LIKE1 (TAGL1) genes, which are members of the tomato MADS-box gene family, influence fruit size in tomatoes (Gimenez et al., 2016). Tomatoes that overexpress $Z j D A 3$, an ortholog of Arabidopsis ubiquitin-specific protease (DA3/UBP14) in Chinese jujube (Ziziphus jujuba Mill.), have reduced fruit size and weight (Guo et al., 2021). The level of endoreduplication in tomatoes was correlated with cell size in fruit pericarp (Cheniclet et al., 2005). The expression of CCS52A (Cell cycle switch protein) or WEE1 (cell cycle-associated protein kinase) genes involving endoreduplication in tomatoes affects cell size and fruit size (Gonzalez et al., 2007; Mathieu-Rivet et al., 2010). Although it is known that miRNA172 influences fruit size regulation in horticultural plants, such as tomato and apple (José Ripoll et al., 2015; Yao et al., 2016), their relationship in tomatoes under $\mathbf{H S}$ is unclear. Four genes are related to fruit shape in tomatoes; FASCIATED (FAS) and LOCULE NUMBER (LC) control flattening and fruit locule number and SUN and OVATE contribute to fruit elongation (Rodríguez et al., 2011). HS increases parthenocarpic fruit production (Pan et al., 2017; Xu et al., 2017; Shinozaki et al., 2018; Pham et al., 2020). Parthenocarpic fruits are induced by several plant hormones, such as GAs and auxin (Ariizumi et al., 2013; Bita and Gerats, 2013; Shinozaki et al., 2020). Additionally, ABA plays a critical role in regulating transcript expression to induce plant defense responses under HS (Scharf et al., 2012; Paupière et al., 2017; Rieu et al., 2017).

In tomatoes, sugar content is closely linked to fruit development (Kanayama, 2017) and is controlled by the phosphoenolpyruvate carboxykinase gene (PEPCK) (Huang et al., 2015), biochemical factors (Beckles et al., 2012), vacuolar processing enzymes (Ariizumi et al., 2011), and putative sucrose sensors (Barker et al., 2000). Total soluble solid (TSS or Brix $^{\circ}$ ) represents the fruit sugar content. TSS content is highly influenced by various biotic and abiotic stresses, including HS, which also damages fruit morphology and quality. Tomatoes have three different developmental stages (Ho, 1996): (i) cell division to increase cell number that contributes to mature fruit size, (ii) rapid cell expansion, and (iii) fruit ripening (Ezura, 2016). Sugar accumulation also generally consists of three steps: first, the vascular system imports the sucrose and water influx; second, starch biosynthesis and sugar metabolism; and third, the breakdown of starch into glucose while fruits soften rapidly (Carrari et al., 2006). In the TSS of tomato fruits, sugars (glucose, galactose, and fructose) contributed the largest portion (Selahle et al., 2014), and TSS commonly ranges from 4 to $6^{\circ}$ Brix among different genotypes.

In tomatoes, the functional amino acid polymorphism of cell wall invertase (LIN5) was encoded by Brix9-2-5, which regulates fruit sugar content (Fridman et al., 2000, 2004). Fruit sugar content and seed development are affected by the inhibition of sucrose transporters. Several sucrose transporters (SUT or SUC) that are essential membrane proteins localized in the phloem sieve element, including LeSUT1, are expressed in leaves; LeSUT2 is expressed in stems, fruits, and anthers, and LeSUT3 is expressed in ovaries and immature fruits (Barker et al., 2000; Weise et al., 2000; Hackel et al., 2006). In addition, five genes encode vascular processing enzymes (SlVPEs): two seed coating type genes, SIVPE1 and SlVPE2, one seed type gene SIVPE4, and two vegetative genes, SIVPE3 and SlVPE5 were reported (Ariizumi et al., 2011). SlVPEs are negative regulators of sugar content in tomato plants. Therefore, using transgenic RNAi lines 
for single or multiple gene expression could be an approach to increase sugar accumulation in tomatoes.

\section{BREEDING MATERIALS AND TECHNOLOGY TO MITIGATE HS INFLUENCE}

The morphological and physiological traits in the vegetative and reproductive phases, that are useful for identifying heattolerant tomatoes, are summarized in Figure 1. Several breeding lines have been recently identified and evaluated by focusing on phenotypes and indicators to generate a heat-tolerant tomato (Table 2). Zhou et al. (2015) described the differences in the quantum efficiency of photosystem II $(\mathrm{F} v / \mathrm{F} m)$ between the heat-tolerant and heat-sensitive groups of tomato entries, and they reported that $\mathrm{F} v / \mathrm{Fm}$ was useful as an early indicator of HS tolerance. Subsequently, Poudyal et al. (2018) evaluated some genotypes using $\mathrm{F} v / \mathrm{Fm}$ and identified some novel heattolerant entries. Paupière et al. (2017) evaluated the accessions of 17 different cultivated and wild tomato phenotypes to high temperatures, focusing on a pollen viability screening approach, and identified thermotolerant and thermosensitive entries. Some heat-tolerant tomato mutants were identified from over 4,000 lines of Micro-Tom tomato mutant collections by evaluating pollen viability, fruit yield, and fruit setting under long-term HS (Pham et al., 2020). Kugblenu et al. (2013) evaluated heat adaptation traits, such as flower drop and fruit number using commercial varieties, that are widely available to farmers in West Africa. Under HS, tomato plants carry the procera (pro) and procera-2 (pro-2) mutants, which are loss-of-function mutants of tomato DELLA (SIDELLA); the hypomorphic allele showed higher fruit set efficiency, and their fruits were parthenocarpic (Shinozaki et al., 2018). In general, there are two main approaches to studying thermotolerance in tomato plants: screening the germplasm (for long-term mild heat treatment) and physiological responses (for short-term heat shock, up to $45^{\circ} \mathrm{C}$ ). Therefore, breeding and genetic engineering strategies can be individually applied or suitably integrated to develop HS tolerant lines or mitigate the effects of HS on tomatoes. Meta-quality trait loci (meta-QTL analysis) and multiparent advanced generation intercross (MAGIC) have been used to provide a higher mapping resolution in heat-tolerant tomato breeding programs. In addition, speed breeding and genomic selection (GS) significantly contribute to thermotolerance in tomatoes (Ayenan et al., 2019; Aleem et al., 2020; Bineau et al., 2021). There are several ways of mitigating the effects of $\mathbf{H S}$ on tomatoes, for example, applying plant growth-promoting rhizobacteria (PGPR) (Mukhtar et al., 2020), or using 6 ppm sulfur (Ali et al., 2021), or nitrate seed priming (Kumar V. et al., 2021). These breeding materials can be used to elucidate the physiological responses conferring adaptation to HS and provide a basis for further studies on the identification of heat-tolerant lines and phenotyping segregating populations.

On the other hand, genetic modification (GM) technology provides rapid and effective cultivars exhibiting tolerance to diverse abiotic stresses, including HS, compared with traditional breeding. There has been some research on the supply of heat tolerance using various genes involved in the regulatory and signaling pathways (Gerszberg et al., 2015) (Table 3). To date, the provision of tolerance to HS was performed using transgenic plants overexpressing TF or HSP involved in transcription regulatory networks, such as HsfA1 (Mishra et al., 2002), hsp21 (Neta-Sharir et al., 2005), MasHSP24.4 (Mahesh et al., 2013), and MT-sHSP (Nautiyal et al., 2005). Transgenic plants expressing yeast S-adenosyl-1-methionine decarboxylase (SAMDC), which is a key regulatory enzyme in polyamine biosynthesis, increased the accumulation of spermidine and spermine and enhanced antioxidant enzyme activity, thereby protecting membrane lipid peroxidation. Subsequently, the plant was protected from HS by improving the efficiency of $\mathrm{CO}_{2}$ assimilation through its enhanced activity and protection (Cheng et al., 2009). Transgenic tomato with an increased anthocyanin-associated R2R3-MYB TF, Lycopersicon esculentum Anthocyanin 2 (LeAN2) overexpression, is highly tolerant to HS (Meng et al., 2015). LeCDJ1 (Lycopersicon esculentum chloroplast-targeted DnaJ protein) is involved in the plant response to ABA. LeCDJ1 overexpressed plant improved growth, chlorophyll content, lower malondialdehyde accumulation, relative electrical conductivity, and less PSII photoinhibition under HS (Kong et al., 2014). Transgenic tomato plants overexpressing choline oxidase (COD), which is involved in glycine betaine $(\mathrm{GB})$ synthesis, showed a high accumulation of GB. The codA-transgenic plants showed increased $\mathrm{CO}_{2}$ assimilation and photosystem II photochemical activity and mitigated the accumulation of $\mathrm{H}_{2} \mathrm{O}_{2}$, superoxide anion radicals, and malondialdehyde. Zhang et al. (2020) suggested the major role of GB in HS tolerance and the importance of $\mathrm{H}_{2} \mathrm{O}_{2}$ as a signaling molecule in heat resistance.

\section{DEVELOPING HEAT-TOLERANT TOMATOES FOR BREEDING}

Genome analysis has progressed significantly and allows us to breed genomes not only in major crops, such as rice but also in vegetables, such as tomatoes. Large-scale phenotypic analysis has also seen significant development. To make the best use of these technologies, it is important to choose traits carefully and conduct the evaluation that suits the objectives, in an appropriate environment. In tropical regions, such as subSaharan Africa (SSA) and Southeast Asia, where rapid population growth is predicted in the future, sustainable production and supply of vegetables will contribute to food security, household improvement of farmers, nutrition improvement of residents, and health promotion. However, currently, most of the vegetables in the tropics are produced and consumed as it is. The primary varieties cultivated are developed by foreign seed companies in developed countries, and these varieties are not very resistant to high temperatures and humidity. Insufficient resistance to diseases results in instability in the yield and quality. Our research team is promoting genome breeding research to develop vegetables, such as tomatoes that are resistant to hightemperature stress, by utilizing unused genetic resources with 
TABLE 2 | Heat-tolerant tomato germplasms and screening conditions.

\begin{tabular}{|c|c|c|c|c|}
\hline $\begin{array}{l}\text { Identified tolerant accessions or } \\
\text { genotype }\end{array}$ & $\begin{array}{l}\text { Screening } \\
\text { environment }\end{array}$ & Screening conditions & Traits and phenotypes & References \\
\hline $\begin{array}{l}\text { LA1500, LA1563, LA1994, LA2093 } \\
\text { (S. pimpinellifolium), LA3120, LA3183, } \\
\text { Bush Italian Roma, Super Sweet }\end{array}$ & $\begin{array}{l}\text { Controlled } \\
\text { environment } \\
\text { Open field (for } \\
\text { validation) }\end{array}$ & $\begin{array}{l}67 \text { genotypes, } 2 \text { heat tolerant } \\
\text { and } 2 \text { heat sensitive for } \\
\text { validation } \\
\mathrm{HS}: 36 / 28^{\circ} \mathrm{C} \text { for } 4 \mathrm{~d} \\
67 \text { genotypes } \\
\mathrm{HS}: 40^{\circ} \mathrm{C} \text { for } 7 \mathrm{~h}\end{array}$ & $\begin{array}{l}\text { Pollen germination rate } \\
\text { Pollen tube length } \\
\text { Fruit set }\end{array}$ & Zhou et al., 2015 \\
\hline $\begin{array}{l}\text { LA2854, LA1478, Nagcarlang, } \\
\text { CL5915-153D4- } \\
\text { 3-3-0, CL1131-0-0-13-0-6, } \\
\text { CLN1621F and CL5915-93D4-1-0-3 } \\
\text { (highest pollen viability) } \\
\text { LA1580, LA2854 (S. pimpinellifolium), } \\
\text { CLN1621F, CL5915-206D4-2-2-0-4, } \\
\text { CLN65-349D5-2-0, M-82, } \\
\text { CL5915-93D4-1-0-3 (highest number } \\
\text { of pollen per flower) }\end{array}$ & $\begin{array}{l}\text { Controlled } \\
\text { environment }\end{array}$ & $\begin{array}{l}\text { HS: } 32 / 26^{\circ} \mathrm{C} \text { (day/night) } \\
\text { Control: } 25 / 19^{\circ} \mathrm{C} \text { (day/night } \\
\text { under } 12-18 \mathrm{~h} \text { of natural day } \\
\text { light for } 1 \text { month) }\end{array}$ & $\begin{array}{l}\text { Number of pollen per flower } \\
\text { Pollen viability }\end{array}$ & Paupière et al., 2017 \\
\hline 15 heat-tolerant tomato mutants & $\begin{array}{l}\text { Controlled environment } \\
\text { Greenhouse }\end{array}$ & $\begin{array}{l}\mathrm{HS}: 35 / 25^{\circ} \mathrm{C}, 16 \mathrm{~h} / 8 \mathrm{~h} \\
\text { light/dark, } 60.0 \mu \mathrm{mol} \mathrm{m} \mathrm{m}^{-2} \mathrm{~s}^{-1} \\
\text { Control: } 25^{\circ} \mathrm{C}, 16 \mathrm{~h} / 8 \mathrm{~h} \\
\text { light/dark, } 60.0 \mu \mathrm{mol} \mathrm{m} \mathrm{m}^{-2} \mathrm{~s}^{-1} \\
\text { Greenhouse: Over } 35^{\circ} \mathrm{C} \text { (daily } \\
\text { maximum temperature) }\end{array}$ & $\begin{array}{l}\text { Flower number } \\
\text { Fruit number } \\
\text { Fruit set } \\
\text { Fruit yield } \\
\text { Average fruit weight } \\
\text { Seed number } \\
\text { SPAD score } \\
\text { Pollen viability Pollen } \\
\text { germination }\end{array}$ & Pham et al., 2020 \\
\hline procera (pro), procera-2 (pro-2) & Greenhouse & $\begin{array}{l}\text { Summer conditions (June- } \\
\text { September 2014) }\end{array}$ & $\begin{array}{l}\text { Fruit number } \\
\text { Fruit set } \\
\text { Fruit yield } \\
\text { Average fruit weight } \\
\text { Stem elongation } \\
\text { Brix value }\end{array}$ & Shinozaki et al., 2018 \\
\hline $\begin{array}{l}69 \text { genotypes ( } 13 \text { and } 19 \% \text { of the } \\
\text { core collection and MAGIC } \\
\text { populations, respectively) }\end{array}$ & Greenhouse & $\begin{array}{l}\text { MAGIC } \\
\text { HS: } 26.9 / 34.4^{\circ} \mathrm{C} \\
\text { Control: } 21.2 / 28.8^{\circ} \mathrm{C} \\
\text { Core collection } \\
\text { HS: } 27.5 / 35.5^{\circ} \mathrm{C} \\
\text { Control: } 22.7 / 31^{\circ} \mathrm{C} \\
\text { Daily mean/maximal } \\
\text { temperatures }\end{array}$ & $\begin{array}{l}\text { Stem diameter } \\
\text { Leaf length } \\
\text { Plant height } \\
\text { Flowering time } \\
\text { Flower number } \\
\text { Fruit number } \\
\text { Fruit set } \\
\text { Average fruit weight } \\
\text { Fruit color } \\
\text { Fruit pH }\end{array}$ & Bineau et al., 2021 \\
\hline
\end{tabular}

excellent traits and making full use of marker selection based on genomic information, especially in SSA and Southeast Asia.

In vegetable breeding, in addition to genome breeding that makes full use of genome information and phenotyping technology, there is great potential for genome editing that has been developed in recent years. In countries with a product-based mindset, unlike traditional GM crops, GM technology is used to generate genome-edited crops, but null segregants do not contain transgenes, which can be suggested using Southern hybridization and PCR (El-Mounadi et al., 2020; Kumar S. et al., 2021). 
TABLE 3 | Representative genes available for improving heat tolerance in tomato plants.

\begin{tabular}{|c|c|c|c|c|}
\hline Gene/locus symbol & Source & Expression & Defined function & References \\
\hline HsfA1 & Tomato & Overexpression & Transcription regulatory network & Mishra et al., 2002 \\
\hline hsp21 & Tomato & Overexpression & $\begin{array}{l}\text { Accumulation of heat shock proteins } \\
\text { Transcription regulatory network }\end{array}$ & Neta-Sharir et al., 2005 \\
\hline MasHSP24.4 & Musa acuminata & Expression & $\begin{array}{l}\text { Accumulation of heat shock proteins } \\
\text { Transcription regulatory network }\end{array}$ & Mahesh et al., 2013 \\
\hline MT-sHSP & Tomato & Expression & $\begin{array}{l}\text { Accumulation of heat shock proteins } \\
\text { Transcription regulatory network }\end{array}$ & Nautiyal et al., 2005 \\
\hline SAMDC & Yeast & Overexpression & Polyamine biosynthesis & Cheng et al., 2009 \\
\hline LeAN2 & Tomato & Overexpression & Anthocyanin-associated R2R3-MYB transcription factor & Meng et al., 2015 \\
\hline LeCDJ1 & Tomato & Overexpression & Chloroplast-targeted DnaJ protein & Kong et al., 2014 \\
\hline $\operatorname{cod} A$ & Tomato & Overexpression & Glycine betaine $(\mathrm{GB})$ synthesis & Zhang et al., 2020 \\
\hline slmapk3 & Tomato & CRISPR/Cas9 & Mitogen-activated protein kinases (MAPKs) family & Yu et al., 2019 \\
\hline
\end{tabular}

In this case, the deregulation process required for GM crops becomes unnecessary; thus, commercialization is relatively easy, and consumers' resistance to GM can be excepted. The University of Tsukuba leads the development and sale of the tomato variety Sicilian Rouge High GABA (Sanatechssed; https://sanatech-seed. com/en/), which has improved GABA contents (a component that has the effect of suppressing blood pressure rise) through genome editing (Nonaka et al., 2017; Lee et al., 2018; Yamamoto et al., 2018; Gramazio et al., 2020). To date, many genes involved in HS resistance have been identified. It is expected that the improved genome editing technology will be used to improve HS resistance by inducing mutations in the negative regulatory genes, which are the key to HS resistance in vegetables, such as tomatoes. Genome editing has already been used to improve stress resistance in tomatoes. For example, the mitogen-activated protein kinase (mapK) 3 gene, slmapK3 gene, branched-amino acid (ALS1), cytidine base editor (CBE) genes, and LATERAL ORGAN BOUNDARIES DOMAIN-LBD TF gene-SILBD40 increased resistance to HS, sulfonylurea herbicide chlorsulfuron, and drought, respectively (Ayenan et al., 2019; Yu et al., 2019; Salava et al., 2021; Xia et al., 2021). Both the achievements of genome editing technology with regard to tomatoes and the identification of key genes, such as HsfA2, HsfB1, JA/COI1, SlAGL6, and SIIAA9, are related to the thermotolerant acquires mechanism in tomatoes, positively contribute to the breeding of heat-tolerant tomato. On the other hand, considering the future movement of products across countries, harmonization between countries that handle genome editing on a product basis and countries that handle genome editing on a process basis is a future concern. Genome editing is an epoch-making technique that can easily cause mutations that occur in nature for the chosen study species. However, there is a concern that consumers will reject it simply because it is a new technology that manipulates the genome. Scientists need to obtain scientific evidence and communicate it to society by communicating closely with governments, producers, consumers, the media, and other stakeholders.

It is necessary to elucidate the physiological mechanisms underlying heat tolerance and facilitate breeding research to improve both tolerance and recovery ability with respect to resilience. Interdisciplinary approaches that go beyond genetic breeding, such as improving HS resistance by utilizing plant-microbial interactions by elucidating the relationship between the microbiome and HS, may also be effective. By utilizing Digital Transformation (DX), which has developed remarkably in recent years, from the viewpoint of Genotype $\mathrm{x}$ Environment $\mathrm{x}$ Management ( $\mathrm{G} \times \mathrm{E} \times \mathrm{M})$, to elucidate the appropriate combination of excellent varieties (genotype), cultivation environment and method (management), model and recommend it to agricultural sites. Utilizing these various innovations may improve climate change adaptation in vegetables, such as tomatoes, by improving HS tolerance in a broad sense.

\section{CONCLUSION}

The latest IPCC report clearly indicates that climate change is currently occurring and will threaten food security in the future. The increasing vulnerability of future food systems is a point of concern. HS, resulting from climate change-induced temperature increase, has a negative impact on all stages of crop growth. For fruiting vegetables, such as tomatoes, even moderate HS reduces fruit set and quality; therefore, enhancing crop HS tolerance is among the best ways to adapt to climate change. In this review, we discuss the important processes that affect the growth and yield of tomatoes, especially HS. This review examines the molecular, morphological, and physiological mechanisms that contribute to HS tolerance and the challenges of developing thermostable vegetable varieties. HS has several complex adverse effects on a wide range of plant growth stages in tomatoes. To understand plant tolerance mechanisms against HS, it is necessary to investigate molecular tolerance mechanisms at each growth stage and type of HS (short or long term). There are several reports on gene regulation networks with respect to short-term HS, but there are few regarding longterm HS. Considering the need to produce heat-tolerant tomato plants, it is crucial to determine how HS occurs in each target area, select germplasm for screening heat tolerance materials, and design molecular pathways to adjust to the target. The nutritional and functional properties of vegetables, including tomatoes, are valuable in terms of global food and nutritional safety assurance. Studies investigating the rapidly increasing HS tolerance and the development of heat-resistant vegetable 
varieties will contribute toward climate change adaptation and the construction of sustainable and resilient food systems to achieve sustainable development goals.

\section{AUTHOR CONTRIBUTIONS}

$\mathrm{KH}$ and $\mathrm{KN}$ wrote the draft of the manuscript. All authors contributed to manuscript revision, read, and approved the submitted version.

\section{REFERENCES}

Ainsworth, E.A., and Rogers, A. (2007). The response of photosynthesis and stomatal conductance to rising $\left[\mathrm{CO}_{2}\right]$ : mechanisms and environmental interactions. Plant Cell Environ. 30, 258-270. doi: 10.1111/j.1365-3040.2007.01641.x

Aleem, S., Sharif, I., Amin, E., Tahir, M., Parveen, N., Aslam, R., et al. (2020). Heat tolerance in vegetables in the current genomic era: an overview. Plant Growth Regul. 20, 1-20. doi: 10.1007/s10725-020-00658-5

Ali, M.M., Waleed Shafique, M., Gull, S., Afzal Naveed, W., Javed, T., Yousef, A.F., et al. (2021). Alleviation of heat stress in tomato by exogenous application of sulfur. Horticulturae 7:21. doi: 10.3390/horticulturae7020021

Allakhverdiev, S.I., Kreslavski, V.D., Klimov, V.V., Los, D.A., Carpentier, R., and Mohanty, P. (2008). Heat stress: an overview of molecular responses in photosynthesis. Photosynthesis Res. 98:541. doi: 10.1007/s11120-0089331-0

Ariizumi, T., Higuchi, K., Arakaki, S., Sano, T., Asamizu, E., and Ezura, H. (2011). Genetic suppression analysis in novel vacuolar processing enzymes reveals their roles in controlling sugar accumulation in tomato fruits. J. Exp. Bot. 62, 2773-2786. doi: 10.1093/jxb/erq451

Ariizumi, T., Shinozaki, Y., and Ezura, H. (2013). Genes that influence yield in tomato. Breed. Sci. 63, 3-13. doi: 10.1270/jsbbs.63.3

Ayenan, M.A.T., Danquah, A., Hanson, P., Ampomah-Dwamena, C., Sodedji, F.A.K., Asante, I.K., et al. (2019). Accelerating breeding for heat tolerance in tomato (Solanum lycopersicum L.): an integrated approach. Agronomy 9:720. doi: 10.3390/agronomy9110720

Balyan, S., Rao, S., Jha, S., Bansal, C., Das, J.R., and Mathur, S. (2020). Characterization of novel regulators for heat stress tolerance in tomato from Indian sub-continent. Plant Biotechnol. J. 18, 2118-2132. doi: $10.1111 /$ pbi.13371

Baniwal, S.K., Bharti, K., Chan, K.Y., Fauth, M., Ganguli, A., Kotak, S., et al. (2004). Heat stress response in plants: a complex game with chaperones and more than twenty heat stress transcription factors. J. Biosci. (Bangalore) 29, 471-487. doi: 10.1007/BF02712120

Barker, L., Kühn, C., Weise, A., Schulz, A., Gebhardt, C., Hirner, B., et al. (2000). SUT2, a putative sucrose sensor in sieve elements. Plant Cell 12, 1153-1164. doi: $10.1105 /$ tpc.12.7.1153

Barnabás, B., Jäger, K., and Fehér, A. (2008). The effect of drought and heat stress on reproductive processes in cereals. Plant Cell Environ. 31, 11-38. doi: 10.1111/j.1365-3040.2007.01727.x

Barrero, L., Cong, B., Wu, F., and Tanksley, S. (2006). Developmental characterization of the fasciated locus and mapping of Arabidopsis candidate genes involved in the control of floral meristem size and carpel number in tomato. Genome 49, 991-1006. doi: 10.1139/g06-059

Beckles, D.M., Hong, N., Stamova, L., and Luengwilai, K. (2012). Biochemical factors contributing to tomato fruit sugar content: a review. Fruits 67, 49-64. doi: $10.1051 /$ fruits/2011066

Bergougnoux, V. (2014). The history of tomato: from domestication to biopharming. Biotechnol. Adv. 32, 170-189. doi: 10.1016/j.biotechadv.2013.11.003

Bineau, E., Diouf, I., Carretero, Y., Duboscq, R., Bitton, F., Djari, A., et al. (2021). Genetic diversity of tomato response to heat stress at the QTL and transcriptome levels. Plant J. 107, 1213-1227. doi: 10.1111/tpj.15379

\section{ACKNOWLEDGMENTS}

We thank Dr. Derek W. Barchenger at the World Vegetable Center for discussion and revision of the review paper. We thank the long-term strategic donors to the World Vegetable Center: Taiwan, aid from the UK government, United States Agency for International Development (USAID), Australian Center for International Agricultural Research (ACIAR), Germany, Thailand, Philippines, Korea, and Japan.

Bita, C., and Gerats, T. (2013). Plant tolerance to high temperature in a changing environment: scientific fundamentals and production of heat stress-tolerant crops. Front. Plant Sci. 4:273. doi: 10.3389/fpls.2013.00273

Bokszczanin, K.L., Fragkostefanakis, S., Bostan, H., Bovy, A., Chaturvedi, P., Chiusano, M.L., et al. (2013). Perspectives on deciphering mechanisms underlying plant heat stress response and thermotolerance. Front. Plant Sci. 4:315. doi: $10.3389 /$ fpls.2013.00315

Bose, J., Rodrigo-Moreno, A., and Shabala, S. (2014). ROS homeostasis in halophytes in the context of salinity stress tolerance. J. Exp. Bot. 65, 1241-1257. doi: $10.1093 /$ jxb/ert430

Busi, M.V., Bustamante, C., D’angelo, C., Hidalgo-Cuevas, M., Boggio, S.B., Valle, E.M., et al. (2003). MADS-box genes expressed during tomato seed and fruit development. Plant Mol. Biol. 52, 801-815. doi: 10.1023/A:1025001402838

Carrari, F., Baxter, C., Usadel, B., Urbanczyk-Wochniak, E., Zanor, M.-I., NunesNesi, A., et al. (2006). Integrated analysis of metabolite and transcript levels reveals the metabolic shifts that underlie tomato fruit development and highlight regulatory aspects of metabolic network behavior. Plant Physiol. 142, 1380-1396. doi: 10.1104/pp.106.088534

Chen, L., Ren, Y., Zhang, Y., Xu, J., Sun, F., Zhang, Z., et al. (2012). Genome-wide identification and expression analysis of heat-responsive and novel microRNAs in Populus tomentosa. Gene 504, 160-165. doi: 10.1016/j.gene.2012.05.034

Cheng, L., Zou, Y., Ding, S., Zhang, J., Yu, X., Cao, J., et al. (2009). Polyamine accumulation in transgenic tomato enhances the tolerance to high temperature stress. J. Integr. Plant Biol. 51, 489-499. doi: 10.1111/j.1744-7909.2009.00816.x

Cheniclet, C., Rong, W.Y., Causse, M., Frangne, N., Bolling, L., Carde, J.-P., et al. (2005). Cell expansion and endoreduplication show a large genetic variability in pericarp and contribute strongly to tomato fruit growth. Plant Physiol. 139, 1984-1994. doi: 10.1104/pp.105.068767

Chusreeaeom, K., Ariizumi, T., Asamizu, E., Okabe, Y., Shirasawa, K., and Ezura, H. (2014). Regulatory change in cell division activity and genetic mapping of a tomato (Solanum lycopersicum L.) elongated-fruit mutant. Plant Biotechnol., 14:0204a. doi: 10.5511/plantbiotechnology.14.0204a

de Jong, M., Mariani, C., and Vriezen, W.H. (2009). The role of auxin and gibberellin in tomato fruit set. J. Exp. Bot. 60, 1523-1532. doi: 10.1093/jxb/erp094

de Martino, G., Pan, I., Emmanuel, E., Levy, A., and Irish, V.F. (2006). Functional analyses of two tomato APETALA3 genes demonstrate diversification in their roles in regulating floral development. Plant Cell 18, 1833-1845. doi: 10.1105/tpc.106.042978

Demidchik, V., Straltsova, D., Medvedev, S.S., Pozhvanov, G.A., Sokolik, A., and Yurin, V. (2014). Stress-induced electrolyte leakage: the role of K+permeable channels and involvement in programmed cell death and metabolic adjustment. J. Exp. Bot. 65, 1259-1270. doi: 10.1093/jxb/eru004

Drake, R., John, I., Farrell, A., Cooper, W., Schuch, W., and Grierson, D. (1996). Isolation and analysis of cDNAs encoding tomato cysteine proteases expressed during leaf senescence. Plant Mol. Biol. 30, 755-767. doi: 10.1007/BF00019009

El-Mounadi, K., Morales-Floriano, M.L., and Garcia-Ruiz, H. (2020). Principles, applications, and biosafety of plant genome editing using CRISPR-Cas9. Front. Plant Sci. 11:56. doi: 10.3389/fpls.2020.00056

El-Shershaby, A., Ullrich, S., Simm, S., Scharf, K.-D., Schleiff, E., and Fragkostefanakis, S. (2019). Functional diversification of tomato HsfA1 factors is based on DNA binding domain properties. Gene 714:143985. doi: 10.1016/j.gene.2019.143985 
Enyedi, A.J., and Pell, E.J. (1992). Comparison of the $r b c L$ gene sequence of two potato cultivars with differential sensitivity to ozone. Plant Physiol. 99:356. doi: $10.1104 /$ pp.99.1.356

Erickson, A., and Markhart, A. (2002). Flower developmental stage and organ sensitivity of bell pepper (Capsicum annuum L.) to elevated temperature. Plant Cell Environ. 25, 123-130. doi: 10.1046/j.0016-8025.2001.00807.x

Ezura, H. (2016). "Toward in silico design and engineering of solanaceae and cucurbitaceae crops," in Functional Genomics and Biotechnology in Solanaceae and Cucurbitaceae Crops. (New York, NY: Springer), 251-258.

Firon, N., Shaked, R., Peet, M., Pharr, D., Zamski, E., Rosenfeld, K., et al. (2006). Pollen grains of heat tolerant tomato cultivars retain higher carbohydrate concentration under heat stress conditions. Sci. Hortic. 109, 212-217. doi: 10.1016/j.scienta.2006.03.007

Fletcher, J.C. (2018). The CLV-WUS stem cell signaling pathway: a roadmap to crop yield optimization. Plants 7:87. doi: 10.3390/plants7040087

Fragkostefanakis, S., Mesihovic, A., Simm, S., Paupière, M.J., Hu, Y., Paul, P., et al. (2016). HsfA2 controls the activity of developmentally and stress-regulated heat stress protection mechanisms in tomato male reproductive tissues. Plant Physiol. 170, 2461-2477. doi: 10.1104/pp.15.01913

Frank, G., Pressman, E., Ophir, R., Althan, L., Shaked, R., Freedman, M., et al. (2009). Transcriptional profiling of maturing tomato (Solanum lycopersicum L.) microspores reveals the involvement of heat shock proteins, ROS scavengers, hormones, and sugars in the heat stress response. J. Exp. Bot. 60, 3891-3908. doi: $10.1093 / \mathrm{jxb} / \mathrm{erp} 234$

Fridman, E., Carrari, F., Liu, Y.-S., Fernie, A.R., and Zamir, D. (2004). Zooming in on a quantitative trait for tomato yield using interspecific introgressions. Science 305, 1786-1789. doi: 10.1126/science.1101666

Fridman, E., Pleban, T., and Zamir, D. (2000). A recombination hotspot delimits a wild-species quantitative trait locus for tomato sugar content to $484 \mathrm{bp}$ within an invertase gene. PNAS. 97, 4718-4723. doi: 10.1073/pnas.97.9.4718

Gerszberg, A., Hnatuszko-Konka, K., Kowalczyk, T., and Kononowicz, A.K. (2015). Tomato (Solanum lycopersicum L.) in the service of biotechnology. Plant Cell, Tissue and Organ Cult. 120, 881-902. doi: 10.1007/s11240-014-0664-4

Gimenez, E., Castañeda, L., Pineda, B., Pan, I.L., Moreno, V., Angosto, T., et al. (2016). TOMATO AGAMOUS1 and ARLEQUIN/TOMATO AGAMOUSLIKE1 MADS-box genes have redundant and divergent functions required for tomato reproductive development. Plant Mol. Biol. 91, 513-531. doi: 10.1007/s11103-016-0485-4

Giorno, F., Wolters-Arts, M., Mariani, C., and Rieu, I. (2013). Ensuring reproduction at high temperatures: the heat stress response during anther and pollen development. Plants 2, 489-506. doi: 10.3390/plants2030489

Gonzalez, N., Gévaudant, F., Hernould, M., Chevalier, C., and Mouras, A. (2007). The cell cycle-associated protein kinase WEE1 regulates cell size in relation to endoreduplication in developing tomato fruit. Plant J. 51, 642-655. doi: 10.1111/j.1365-313X.2007.03167.x

Gramazio, P., Takayama, M., and Ezura, H. (2020). Challenges and prospects of new plant breeding techniques for GABA improvement in crops: tomato as an example. Front. Plant Sci. 11:980. doi: 10.3389/fpls.2020.577980

Guo, M., Zhang, Z., Li, S., Lian, Q., Fu, P., He, Y., et al. (2021). Genomic analyses of diverse wild and cultivated accessions provide insights into the evolutionary history of jujube. Plant Biotechnol. J. 19, 517-531. doi: 10.1111/pbi.13480

Hackel, A., Schauer, N., Carrari, F., Fernie, A.R., Grimm, B., and Kühn, C. (2006). Sucrose transporter LeSUT1 and LeSUT2 inhibition affects tomato fruit development in different ways. Plant J. 45, 180-192. doi: 10.1111/j.1365-313X.2005.02572.x

Hasanuzzaman, M., Nahar, K., Alam, M., Roychowdhury, R., and Fujita, M. (2013). Physiological, biochemical, and molecular mechanisms of heat stress tolerance in plants. Int. J. Mol. Sci. 14, 9643-9684. doi: 10.3390/ijms14059643

Hashimoto, M., Negi, J., Young, J., Israelsson, M., Schroeder, J.I., and Iba, K. (2006). Arabidopsis HT1 kinase controls stomatal movements in response to $\mathrm{CO}_{2}$. Nat. Cell Biol. 8, 391-397. doi: 10.1038/ncb1387

Hendelman, A., Stav, R., Zemach, H., and Arazi, T. (2013). The tomato NAC transcription factor SlNAM2 is involved in flower-boundary morphogenesis. J. Exp. Bot. 64, 5497-5507. doi: 10.1093/jxb/ert324

Higashi, Y., Ohama, N., Ishikawa, T., Katori, T., Shimura, A., Kusakabe, K., et al. (2013). HsfAld, a protein identified via FOX hunting using Thellungiella salsuginea cDNAs improves heat tolerance by regulating heat-stress-responsive gene expression. Mol. Plant 6, 411-422. doi: 10.1093/mp/sst024
Ho, L.C. (1996). The mechanism of assimilate partitioning and carbohydrate compartmentation in fruit in relation to the quality and yield of tomato. J. Exp. Bot. 47, 1239-1243. doi: 10.1093/jxb/47.Special_Issue.1239

Horváth, E., Szalai, G., and Janda, T. (2007). Induction of abiotic stress tolerance by salicylic acid signaling. J. Plant Growth Regul. 26, 290-300. doi: 10.1007/s00344-007-9017-4

Hu, X., Jiang, M., Zhang, A., and Lu, J. (2005). Abscisic acid-induced apoplastic $\mathrm{H}_{2} \mathrm{O}_{2}$ accumulation up-regulates the activities of chloroplastic and cytosolic antioxidant enzymes in maize leaves. Planta 223, 57-68. doi: 10.1007/s00425-005-0068-0

Huang, Y.-X., Goto, Y., Nonaka, S., Fukuda, N., Ezura, H., and Matsukura, C. (2015). Overexpression of the phosphoenolpyruvate carboxykinase gene (SIPEPCK) promotes soluble sugar accumulation in fruit and post-germination growth of tomato (Solanum lycopersicum L.). Plant Biotechnol. 32, 281-289. doi: 10.5511/plantbiotechnology.15.1019a

Ikeda, M., Mitsuda, N., and Ohme-Takagi, M. (2011). Arabidopsis HsfB1 and HsfB2b act as repressors of the expression of heat-inducible Hsfs but positively regulate the acquired thermotolerance. Plant Physiol. 157, 1243-1254. doi: 10.1104/pp.111.179036

Ilík, P., Špundová, M., Šicner, M., Melkovičová, H., and Kučerová, Z., Krchnák, P., et al. (2018). Estimating heat tolerance of plants by ion leakage: a new method based on gradual heating. New Phytol. 218, 1278-1287. doi: 10.1111/nph. 15097

Jahan, M.S., Wang, Y., Shu, S., Zhong, M., Chen, Z., Wu, J., et al. (2019). Exogenous salicylic acid increases the heat tolerance in Tomato (Solanum lycopersicum L) by enhancing photosynthesis efficiency and improving antioxidant defense system through scavenging of reactive oxygen species. Sci. Hortic. 247, 421-429. doi: 10.1016/j.scienta.2018.12.047

Ji, G., Xue, H., Seneweera, S., Ping, L., Zong, Y.-,Z., Qi, D., et al. (2015). Leaf photosynthesis and yield components of mung bean under fully open-air elevated $\left[\mathrm{CO}_{2}\right]$. J. Integr. Agric. 14, 977-983. doi: 10.1016/S2095-3119(14)60941-2

Jofuku, K.D., Den Boer, B., Van Montagu, M., and Okamuro, J.K. (1994). Control of Arabidopsis flower and seed development by the homeotic gene APETALA2. Plant Cell 6, 1211-1225. doi: 10.1105/tpc.6.9.1211

Jones, D.S., John, A., VanDerMolen, K.R., and Nimchuk, Z.L. (2021). CLAVATA signaling ensures reproductive development in plants across thermal environments. Curr. Biol. 31, 220-227. doi: 10.1016/j.cub.2020.10.008

Jones, P.D., New, M., Parker, D.E., Martin, S., and Rigor, I.G. (1999). Surface air temperature and its changes over the past 150 years. Rev. Geophys. 37, 173-199. doi: 10.1029/1999RG900002

José Ripoll, J., Bailey, L.J., Mai, Q.A., Wu, S.L., Hon, C.T., Chapman, E.J., et al. (2015). microRNA regulation of fruit growth. Nat Plants 1:15036. doi: $10.1038 /$ nplants.2015.36

Kanayama, Y. (2017). Sugar metabolism and fruit development in the tomato. Hort. J. OKD-IR01. doi: 10.2503/hortj.OKD-IR01

Keller, M., and Simm, S. (2018). The coupling of transcriptome and proteome adaptation during development and heat stress response of tomato pollen. $B M C$ Genom. 19, 1-20. doi: 10.1186/s12864-018-4824-5

Klap, C., Yeshayahou, E., Bolger, A.M., Arazi, T., Gupta, S.K., Shabtai, S., et al. (2017). Tomato facultative parthenocarpy results from Sl AGAMOUS-LIKE 6 loss of function. Plant Biotechnol. J. 15, 634-647. doi: 10.1111/pbi.12662

Kong, F., Deng, Y., Wang, G., Wang, J., Liang, X., and Meng, Q. (2014). LeCDJ1, a chloroplast DnaJ protein, facilitates heat tolerance in transgenic tomatoes. J. Integr. Plant Biol. 56, 63-74. doi: 10.1111/jipb.12119

Kotak, S., Larkindale, J., Lee, U., von Koskull-Döring, P., Vierling, E., and Scharf, K.-D. (2007). Complexity of the heat stress response in plants. Curr. Opin. Plant Biol. 10, 310-316. doi: 10.1016/j.pbi.2007.04.011

Kramer, E.M., Dorit, R.L., and Irish, V.F. (1998). Molecular evolution of genes controlling petal and stamen development: duplication and divergence within the APETALA3 and PISTILLATA MADS-box gene lineages. Genetics 149, 765-783. doi: 10.1093/genetics/149.2.765

Kugblenu, Y.O., Oppong Danso, E., Ofori, K., Andersen, M.N., Abenney-Mickson, S., Sabi, E.B., et al. (2013). Screening tomato genotypes for adaptation to high temperature in West Africa. Acta Agric. Scand. B Soil Plant Sci. 63, 516-522. doi: 10.1080/09064710.2013.813062

Kumar, S., Kaur, R., Kaur, N., Bhandhari, K., Kaushal, N., Gupta, K., et al. (2011). Heat-stress induced inhibition in growth and chlorosis in mungbean (Phaseolus aureus Roxb.) is partly mitigated by ascorbic acid application and 
is related to reduction in oxidative stress. Acta Physiol. Plant. 33, 2091-2101. doi: 10.1007/s11738-011-0748-2

Kumar, S., Rymarquis, L.A., Ezura, H., and Nekrasov, V. (2021). Editorial: CRISPR-Cas in agriculture: opportunities and challenges. Front. Plant Sci. 12, 672329-672329. doi: 10.3389/fpls.2021.672329

Kumar, V., Dwivedi, P., Kumar, P., Singh, B.N., Pandey, D.K., Kumar, V., et al. (2021). Mitigation of heat stress responses in crops using nitrate primed seeds. S. Afr. J. Bot. 140, 25-36. doi: 10.1016/j.sajb.2021.03.024

Lahr, E.C., Schade, G.W., Crossett, C.C., and Watson, M.R. (2015). Photosynthesis and isoprene emission from trees along an urban-rural gradient in Texas. Global Change Biol. 21, 4221-4236. doi: 10.1111/gcb.13010

Lee, J., Nonaka, S., Takayama, M., and Ezura, H. (2018). Utilization of a genomeedited tomato (Solanum lycopersicum) with high gamma aminobutyric acid content in hybrid breeding. J. Agric. Food Chem. 66, 963-971. doi: 10.1021/acs.jafc.7b05171

Lin, Y.-X., Jiang, H.-Y., Chu, Z.-X., Tang, X.-L., Zhu, S.-W., and Cheng, B.J. (2011). Genome-wide identification, classification and analysis of heat shock transcription factor family in maize. BMC Genomics 12, 1-14. doi: 10.1186/1471-2164-12-76

Liu, H.C., Liao, H.T., and Charng, Y.Y. (2011). The role of class A1 heat shock factors (HSFA1s) in response to heat and other stresses in Arabidopsis. Plant Cell Environ. 34, 738-751. doi: 10.1111/j.1365-3040.2011.02278.x

Mahesh, U., Mamidala, P., Rapolu, S., Aragao, F.J., Souza, M., Rao, P., et al. (2013). Constitutive overexpression of small HSP24. 4 gene in transgenic tomato conferring tolerance to high-temperature stress. Mol. Breed. 32, 687-697. doi: 10.1007/s11032-013-9901-5

Mathieu-Rivet, E., Gévaudant, F., Sicard, A., Salar, S., Do, P.T., Mouras, A., et al. (2010). Functional analysis of the anaphase promoting complex activator CCS52A highlights the crucial role of endo-reduplication for fruit growth in tomato. Plant J. 62, 727-741. doi: 10.1111/j.1365-313X.2010.04198.x

Matsukura, C., Aoki, K., Fukuda, N., Mizoguchi, T., Asamizu, E., Saito, T., et al. (2008). Comprehensive resources for tomato functional genomics based on the miniature model tomato Micro-Tom. Curr. Genomics 9, 436-443. doi: $10.2174 / 138920208786241225$

Medlyn, B.E., Barton, C., Broadmeadow, M., Ceulemans, R., De Angelis, P., Forstreuter, M., et al. (2001). Stomatal conductance of forest species after longterm exposure to elevated $\mathrm{CO}_{2}$ concentration: a synthesis. New Phytol. 149, 247-264. doi: 10.1046/j.1469-8137.2001.00028.x

Meng, X., Wang, J.-R., Wang, G.-D., Liang, X.-Q., Li, X.-D., and Meng, Q.-W. (2015). An R2R3-MYB gene, LeAN2, positively regulated the thermo-tolerance in transgenic tomato. J. Plant Physiol. 175, 1-8. doi: 10.1016/j.jplph.2014.09.018

Mishra, S.K., Tripp, J., Winkelhaus, S., Tschiersch, B., Theres, K., Nover, L., et al. (2002). In the complex family of heat stress transcription factors, HsfA1 has a unique role as master regulator of thermotolerance in tomato. Genes Dev. 16, 1555-1567. doi: 10.1101/gad.228802

Miura, K., and Tada, Y. (2014). Regulation of water, salinity, and cold stress responses by salicylic acid. Front. Plant Sci. 5:4. doi: 10.3389/fpls.2014.00004

Monterroso, V.A., and Wien, H.C. (1990). Flower and pod abscission due to heat stress in beans. J. Am. Soc. Hort. Sci. 115, 631-634. doi: 10.21273/JASHS.115.4.631

Mukhtar, T., Smith, D., Sultan, T., Seleiman, M.F., Alsadon, A.A., Ali, S., et al. (2020). Mitigation of heat stress in Solanum lycopersicum L. by ACC-deaminase and exopolysaccharide producing Bacillus cereus: effects on biochemical profiling. Sustainability 12:2159. doi: 10.3390/su12062159

Müller, F., Xu, J., Kristensen, L., Wolters-Arts, M., de Groot, P.F., Jansma, S.Y., et al. (2016). High-temperature-induced defects in tomato (Solanum lycopersicum) anther and pollen development are associated with reduced expression of B-class floral patterning genes. PLOS ONE 11:e0167614. doi: 10.1371/journal.pone.0167614

Murai, K. (2013). Homeotic genes and the ABCDE model for floral organ formation in wheat. Plants 2, 379-395. doi: 10.3390/plants2030379

Nautiyal, P.C., Shono, M., and Egawa, Y. (2005). Enhanced thermotolerance of the vegetative part of MT-sHSP transgenic tomato line. Sci. Hortic. 105, 393-409. doi: 10.1016/j.scienta.2005.02.001

Negi, J., Matsuda, O., Nagasawa, T., Oba, Y., Takahashi, H., Kawai-Yamada, M., et al. (2008). $\mathrm{CO}_{2}$ regulator SLAC1 and its homologues are essential for anion homeostasis in plant cells. Nature 452, 483-486. doi: 10.1038/nature06720
Neill, S., Barros, R., Bright, J., Desikan, R., Hancock, J., Harrison, J., et al. (2008). Nitric oxide, stomatal closure, and abiotic stress. J. Exp. Bot. 59, 165-176. doi: $10.1093 /$ jxb/erm 293

Neta-Sharir, I., Isaacson, T., Lurie, S., and Weiss, D. (2005). Dual role for tomato heat shock protein 21: protecting photosystem II from oxidative stress and promoting color changes during fruit maturation. Plant Cell 17, 1829-1838. doi: $10.1105 /$ tpc. 105.031914

Nonaka, S., Arai, C., Takayama, M., Matsukura, C., and Ezura, H. (2017). Efficient increase of $\gamma$-aminobutyric acid (GABA) content in tomato fruits by targeted mutagenesis. Sci. Rep. 7, 1-14. doi: 10.1038/s41598-017-06400-y

Ohama, N., Kusakabe, K., Mizoi, J., Zhao, H., Kidokoro, S., Koizumi, S., et al. (2016). The transcriptional cascade in the heat stress response of Arabidopsis is strictly regulated at the level of transcription factor expression. Plant Cell 28, 181-201. doi: 10.1105/tpc.15.00435

Ohama, N., Sato, H., Shinozaki, K., and Yamaguchi-Shinozaki, K. (2017). Transcriptional regulatory network of plant heat stress response. Trends Plant Sci. 22, 53-65. doi: 10.1016/j.tplants.2016.08.015

Pan, C., Yang, D., Zhao, X., Jiao, C., Yan, Y., Lamin-Samu, A.T., et al. (2019). Tomato stigma exsertion induced by high temperature is associated with the jasmonate signalling pathway. Plant, Cell Environ. 42, 1205-1221. doi: $10.1111 /$ pce. 13444

Pan, C., Ye, L., Zheng, Y., Wang, Y., Yang, D., Liu, X., et al. (2017). Identification and expression profiling of microRNAs involved in the stigma exsertion under high-temperature stress in tomato. BMC Genomics 18, 1-16. doi: 10.1186/s12864-017-4238-9

Paupière, M.J., van Haperen, P., Rieu, I., Visser, R.G., Tikunov, Y.M., and Bovy, A.G. (2017). Screening for pollen tolerance to high temperatures in tomato. Euphytica 213, 1-8. doi: 10.1007/s10681-017-1927-z

Peet, M., Sato, S., and Gardner, R. (1998). Comparing heat stress effects on male-fertile and male-sterile tomatoes. Plant Cell Environ. 21, 225-231. doi: 10.1046/j.1365-3040.1998.00281.x

Pham, D., Hoshikawa, K., Fujita, S., Fukumoto, S., Hirai, T., Shinozaki, Y., et al. (2020). A tomato heat-tolerant mutant shows improved pollen fertility and fruit-setting under long-term ambient high temperature. Environ. Exp. Bot. 178:104150. doi: 10.1016/j.envexpbot.2020.104150

Piramila, B., Prabha, A., Nandagopalan, V., and Stanley, A. (2012). Effect of heat treatment on germination, seedling growth and some biochemical parameters of dry seeds of black gram. Int. J. Pharm. Phytopharmacol. Res 1, 194-202.

Potters, G., Pasternak, T.P., Guisez, Y., and Jansen, M.A. (2009). Different stresses, similar morphogenic responses: integrating a plethora of pathways. Plant Cell Environ. 32, 158-169. doi: 10.1111/j.1365-3040.2008. 01908.x

Poudyal, D., Rosenqvist, E., and Ottosen, C.-O. (2018). Phenotyping from lab to field-tomato lines screened for heat stress using $\mathrm{Fv} / \mathrm{Fm}$ maintain high fruit yield during thermal stress in the field. Funct. Plant Biol. 46, 44-55. doi: 10.1071/FP17317

Prasad, P.V., Craufurd, P., and Summerfield, R. (1999). Fruit number in relation to pollen production and viability in groundnut exposed to short episodes of heat stress. Ann. Bot. 84, 381-386. doi: 10.1006/anbo.1999.0926

Qu, A.-L., Ding, Y.-F., Jiang, Q., and Zhu, C. (2013). Molecular mechanisms of the plant heat stress response. Biochem. Biophys. Res. Commun. 432, 203-207. doi: 10.1016/j.bbrc.2013.01.104

Quinet, M., Angosto, T., Yuste-Lisbona, F.J., Blanchard-Gros, R., Bigot, S., Martinez, J.-P., et al. (2019). Tomato fruit development and metabolism. Front. Plant Sci. 10, 1554. doi: 10.3389/fpls.2019.01554

Radin, J.W., Lu, Z., Percy, R.G., and Zeiger, E. (1994). Genetic variability for stomatal conductance in Pima cotton and its relation to improvements of heat adaptation. PNAS. 91, 7217-7221. doi: 10.1073/pnas.91.15.7217

Raja, M.M., Vijayalakshmi, G., Naik, M.L., Basha, P.O., Sergeant, K., Hausman, J.F., et al. (2019). Pollen development and function under heat stress: from effects to responses. Acta Physiol. Plant. 41, 1-20. doi: 10.1007/s11738-019-2835-8

Rao, S., Das, J.R., and Mathur, S. (2021). Exploring the master regulator heat stress transcription factor HSFAla-mediated transcriptional cascade of HSFs in the heat stress response of tomato. J. Plant Biochem. Biotechnol. doi: 10.1007/s13562-021-00696-8

Reynolds, M.P., Pierre, C.S., Saad, A.S., Vargas, M., and Condon, A.G. (2007). Evaluating potential genetic gains in wheat associated with stress-adaptive trait 
expression in elite genetic resources under drought and heat stress. Crop Sci. 47, S-172-S-189. doi: 10.2135/cropsci2007.10.0022IPBS

Reynolds-Henne, C.E., Langenegger, A., Mani, J., Schenk, N., Zumsteg, A., and Feller, U. (2010). Interactions between temperature, drought and stomatal opening in legumes. Environ. Exp. Bot. 68, 37-43. doi: 10.1016/j.envexpbot.2009.11.002

Rieu, I., Twell, D., and Firon, N. (2017). Pollen development at high temperature: from acclimation to collapse. Plant Physiol. 173, 1967-1976. doi: $10.1104 /$ pp. 16.01644

Rijpkema, A.S., Vandenbussche, M., Koes, R., Heijmans, K., and Gerats, T. (2010). Variations on a theme: changes in the floral ABCs in angiosperms. Semin. Cell Dev. Biol. 10, 100-107. doi: 10.1016/j.semcdb.2009.11.002

Rodríguez, G.R., Muños, S., Anderson, C., Sim, S.-C., Michel, A., Causse, M., et al. (2011). Distribution of SUN, OVATE, LC, and FAS in the tomato germplasm and the relationship to fruit shape diversity. Plant Physiol. 156, 275-285. doi: 10.1104/pp.110.167577

Rodríguez-Leal, D., Lemmon, Z.H., Man, J., Bartlett, M.E., and Lippman, Z.B. (2017). Engineering quantitative trait variation for crop improvement by genome editing. Cell 171, 470-480. doi: 10.1016/j.cell.2017.08.030

Saeed, A., Hayat, K., Khan, A., and Iqbal, S. (2007). Heat tolerance studies in tomato (Lycopersicon esculentum Mill.). Int. J. Agric. Biol. 9, 649-652.

Saito, T., Ariizumi, T., Okabe, Y., Asamizu, E., Hiwasa-Tanase, K., Fukuda, N., et al. (2011). TOMATOMA: a novel tomato mutant database distributing Micro-Tom mutant collections. Plant Cell Physiol. 52, 283-296. doi: $10.1093 / \mathrm{pcp} / \mathrm{pcr} 004$

Sakata, T., and Higashitani, A. (2008). Male sterility accompanied with abnormal anther development in plants-genes and environmental stresses with special reference to high temperature injury. Int. J. Plant Dev. Biol. 2:4.

Salava, H., Thula, S., Mohan, V., Kumar, R., and Maghuly, F. (2021). Application of genome editing in tomato breeding: mechanisms, advances, and prospects. Int. J. Mol. Sci. 22:682. doi: 10.3390/ijms22020682

Sato, S., Kamiyama, M., Iwata, T., Makita, N., Furukawa, H., and Ikeda, H. (2006). Moderate increase of mean daily temperature adversely affects fruit set of Lycopersicon esculentum by disrupting specific physiological processes in male reproductive development. Ann. Bot. 97, 731-738. doi: 10.1093/aob/mcl037

Sato, S., Peet, M., and Thomas, J. (2000). Physiological factors limit fruit set of tomato (Lycopersicon esculentum Mill.) under chronic, mild heat stress. Plant Cell Environ. 23, 719-726. doi: 10.1046/j.1365-3040.2000.00589.x

Sato, S., Peet, M.M., and Thomas, J.F. (2002). Determining critical pre-and postanthesis periods and physiological processes in Lycopersicon esculentum Mill. exposed to moderately elevated temperatures. J. Exp. Bot. 53, 1187-1195. doi: $10.1093 /$ jexbot/53.371.1187

Scharf, K.-D., Berberich, T., Ebersberger, I., and Nover, L. (2012). The plant heat stress transcription factor (Hsf) family: structure, function and evolution. Biochim. Biophys. Acta Gene Regul. Mech. 1819, 104-119. doi: 10.1016/j.bbagrm.2011.10.002

Schauer, S.E., Schlüter, P.M., Baskar, R., Gheyselinck, J., Bolaños, A., Curtis, M.D., et al. (2009). Intronic regulatory elements determine the divergent expression patterns of AGAMOUS-LIKE6 subfamily members in Arabidopsis. Plant J. 59, 987-1000. doi: 10.1111/j.1365-313X.2009.03928.x

Selahle, M. K., Sivakumar, D., and Soundy, P. (2014). Effect of photo-selective nettings on post-harvest quality and bioactive compounds in selected tomato cultivars. J. Sci. Food Agri. 94, 2187-2195. doi: 10.1002/jsfa.6536

Shanmugam, S., Kjaer, K.H., Ottosen, C.O., Rosenqvist, E., Kumari Sharma, D., and Wollenweber, B. (2013). The alleviating effect of elevated $\mathrm{CO}_{2}$ on heat stress susceptibility of two wheat (Triticum aestivum L.) Cultivars. J. Agron. Crop Sci. 199, 340-350. doi: 10.1111/jac.12023

Sharkey, T.D., and Zhang, R. (2010). High temperature effects on electron and proton circuits of photosynthesis. J. Integr. Plant Biol. 52, 712-722. doi: 10.1111/j.1744-7909.2010.00975.x

Sharma, B., Yant, L., Hodges, S.A., and Kramer, E.M. (2014). Understanding the development and evolution of novel floral form in Aquilegia. Curr. Opin. Plant Biol. 17, 22-27. doi: 10.1016/j.pbi.2013.10.006

Shi, H., Jiang, C., Ye, T., Tan, D.-X., Reiter, R.J., Zhang, H., et al. (2015). Comparative physiological, metabolomic, and transcriptomic analyses reveal mechanisms of improved abiotic stress resistance in bermudagrass [Cynodon dactylon (L). Pers.] by exogenous melatonin. J. Exp. Bot. 66, 681-694. doi: $10.1093 /$ jxb/eru373
Shikata, M., Hoshikawa, K., Ariizumi, T., Fukuda, N., Yamazaki, Y., and Ezura, H. (2016). TOMATOMA update: Phenotypic and metabolite information in the Micro-Tom mutant resource. Plant Cell Physiol. 57, e11-e11. doi: $10.1093 / \mathrm{pcp} / \mathrm{pcv} 194$

Shinozaki, Y., Beauvoit, B.P., Takahara, M., Hao, S., Ezura, K., Andrieu, M.-H., et al. (2020). Fruit setting rewires central metabolism via gibberellin cascades. PNAS. 117, 23970-23981. doi: 10.1073/pnas. 2011859117

Shinozaki, Y., Ezura, K., Hu, J., Okabe, Y., Bénard, C., Prodhomme, D., et al. (2018). Identification and functional study of a mild allele of SIDELLA gene conferring the potential for improved yield in tomato. Sci. Rep. 8, 1-15. doi: 10.1038/s41598-018-30502-w

Smaczniak, C., Immink, R.G., Angenent, G.C., and Kaufmann, K. (2012). Developmental and evolutionary diversity of plant MADS-domain factors: insights from recent studies. Development 139, 3081-3098. doi: 10.1242/dev.074674

Smertenko, A., DRÁBER, P., Viklick,ý, V., and Opatrn,ý, Z. (1997). Heat stress affects the organization of microtubules and cell division in Nicotiana tabacum cells. Plant, Cell Environ. 20, 1534-1542. doi: 10.1046/j.1365-3040.1997.d01-44.x

Somssich, M., Je, B.I., Simon, R., and Jackson, D. (2016). CLAVATAWUSCHEL signaling in the shoot meristem. Development 143, 3238-3248. doi: 10.1242/dev.133645

Stocker, T., Qin, D., Plattner, G., Tignor, M., Allen, S., Boschung, J., et al. (2013). IPCC, 2013: summary for policymakers in climate change 2013: the physical science basis, contribution of working group I to the fifth assessment report of the intergovernmental panel on climate change. Camb. Univ. Press Camb. UKNY NY USA.

Takeoka, Y., Hiroi, K., Kitano, H., and Wada, T. (1991). Pistil hyperplasia in rice spikelets as affected by heat stress. Sex. Plant Reprod. 4, 39-43. doi: 10.1007/BF00194570

Thirumalaikumar, V.P., Devkar, V., Mehterov, N., Ali, S., Ozgur, R., Turkan, I., et al. (2018). NAC transcription factor JUNGBRUNNEN 1 enhances drought tolerance in tomato. Plant Biotechnol. J. 16, 354-366. doi: 10.1111/pbi. 12776

Todorov, D.T., Karanov, E.N., Smith, A.R., and Hall, M.A. (2003). Chlorophyllase activity and chlorophyll content in wild and mutant plants of Arabidopsis thaliana. Biol. Plant. 46, 125-127. doi: 10.1023/A:1022355525907

Toh, S., Imamura, A., Watanabe, A., Nakabayashi, K., Okamoto, M., Jikumaru, Y., et al. (2008). High temperature-induced abscisic acid biosynthesis and its role in the inhibition of gibberellin action in Arabidopsis seeds. Plant Physiol. 146, 1368-1385. doi: 10.1104/pp.107.113738

Valladares, F., and Pearcy, R. (1997). Interactions between water stress, sun-shade acclimation, heat tolerance and photoinhibition in the sclerophyll Heteromeles arbutifolia. Plant Cell Environ. 20, 25-36. doi: 10.1046/j.1365-3040.1997.d01-8.x

Vara Prasad, P.V., Craufurd, P.Q., Summerfield, R.J., and Wheeler, T.R. (2000). Effects of short episodes of heat stress on flower production and fruit-set of groundnut (Arachis hypogaea L.). J. Exp. Bot. 51, 777-784. doi: $10.1093 /$ jxb/51.345.777

Vollenweider, P., and Günthardt-Goerg, M.S. (2005). Diagnosis of abiotic and biotic stress factors using the visible symptoms in foliage. Environ. Pollut. 137, 455-465. doi: 10.1016/j.envpol.2005.01.032

von Caemmerer, S., and Evans, J.R. (2015). Temperature responses of mesophyll conductance differ greatly between species. Plant Cell Environ. 38, 629-637. doi: $10.1111 /$ pce. 12449

Wahid, A., Gelani, S., Ashraf, M., and Foolad, M.R. (2007). Heat tolerance in plants: an overview. Environ. Exp. Bot. 61, 199-223. doi: 10.1016/j.envexpbot.2007.05.011

Wahid, A., and Shabbir, A. (2005). Induction of heat stress tolerance in barley seedlings by pre-sowing seed treatment with glycinebetaine. Plant Growth Regul. 46, 133-141. doi: 10.1007/s10725-005-8379-5

Wang, G., Kong, F., Zhang, S., Meng, X., Wang, Y., and Meng, Q. (2015). A tomato chloroplast-targeted DnaJ protein protects Rubisco activity under heat stress. J. Exp. Bot. 66, 3027-3040. doi: 10.1093/jxb/erv102

Wang, W., Vinocur, B., Shoseyov, O., and Altman, A. (2004). Role of plant heatshock proteins and molecular chaperones in the abiotic stress response. Trends Plant Sci. 9, 244-252. doi: 10.1016/j.tplants.2004.03.006 
Warrag, M., and Hall, A. (1984). Reproductive responses of cowpea (Vigna unguiculata (L.) Walp.) to heat stress. II. Responses to night air temperature. Field Crops Res. 8, 17-33. doi: 10.1016/0378-4290(84)90049-2

Watanabe, S., Mizoguchi, T., Aoki, K., Kubo, Y., Mori, H., Imanishi, S., et al. (2007). Ethylmethanesulfonate (EMS) mutagenesis of Solanum lycopersicum cv. Micro-Tom for large-scale mutant screens. Plant Biotechnol. 24, 33-38. doi: 10.5511/plantbiotechnology.24.33

Weise, A., Barker, L., Kühn, C., Lalonde, S., Buschmann, H., Frommer, W.B., et al. (2000). A New subfamily of sucrose transporters, sut4, with low affinity/high capacity localized in enucleate sieve elements of plants. Plant Cell 12, 1345-1355. doi: 10.1105/tpc.12.8.1345

Wellmer, F., Graciet, E., and Riechmann, J.L. (2014). Specification of floral organs in Arabidopsis. J. Exp. Bot. 65, 1-9. doi: 10.1093/jxb/ert385

Weston, D.J., and Bauerle, W.L. (2007). Inhibition and acclimation of $\mathrm{C}_{3}$ photosynthesis to moderate heat: a perspective from thermally contrasting genotypes of Acer rubrum (red maple). Tree Physiol. 27, 1083-1092. doi: $10.1093 /$ treephys/27.8.1083

Woo, H.R., Kim, H.J., Nam, H.G., and Lim, P.O. (2013). Plant leaf senescence and death-regulation by multiple layers of control and implications for aging in general. J. Cell Sci. 126, 4823-4833. doi: 10.1242/jcs.109116

Xia, X., Cheng, X., Li, R., Yao, J., Li, Z., and Cheng, Y. (2021). Advances in application of genome editing in tomato and recent development of genome editing technology. Theor. Appl. Genet. 21, 1-21. doi: 10.1007/s00122-021-03874-3

Xiao, H.-J., Yin, Y.-X., Chai, W.-G., and Gong, Z.-H. (2014). Silencing of the CaCP gene delays salt-and osmotic-induced leaf senescence in Capsicum annuum L. Int. J. Mol. Sci. 15, 8316-8334. doi: 10.3390/ijms15058316

Xu, C., Liberatore, K.L., MacAlister, C.A., Huang, Z., Chu, Y.-H., Jiang, K., et al. (2015). A cascade of arabinosyltransferases controls shoot meristem size in tomato. Nat. Genet. 47, 784-792. doi: 10.1038/ng.3309

$\mathrm{Xu}, \quad$ H.H., and Tabita, F.R. (1996). Ribulose-1, 5-bisphosphate carboxylase/oxygenase gene expression and diversity of Lake Erie planktonic microorganisms. Appl. Environ. Microbiol. 62, 1913-1921. doi: 10.1128/aem.62.6.1913-1921.1996

Xu, J., Wolters-Arts, M., Mariani, C., Huber, H., and Rieu, I. (2017). Heat stress affects vegetative and reproductive performance and trait correlations in tomato (Solanum lycopersicum). Euphytica 213, 1-12. doi: 10.1007/s10681-017-1949-6

Yamamoto, T., Kashojiya, S., Kamimura, S., Kameyama, T., Ariizumi, T., Ezura, H., et al. (2018). Application and development of genome editing technologies to the Solanaceae plants. Plant Physiol. Biochem. 131, 37-46. doi: 10.1016/j.plaphy.2018.02.019

Yan, W.G., Li, Y., Agrama, H.A., Luo, D., Gao, F., Lu, X., et al. (2009). Association mapping of stigma and spikelet characteristics in rice (Oryza sativa L.). Mol. Breed. 24, 277-292. doi: 10.1007/s11032-009-9290-y

Yao, J.-L., Tomes, S., Xu, J., and Gleave, A.P. (2016). How microRNA172 affects fruit growth in different species is dependent on fruit type. Plant Signal Behav. 11, 417-427. doi: 10.1080/15592324.2016.1156833

Yoshida, T., Ohama, N., Nakajima, J., Kidokoro, S., Mizoi, J., Nakashima, K., et al. (2011). Arabidopsis HsfA1 transcription factors function as the main positive regulators in heat shock-responsive gene expression. Mol. Genet. Genomics 286, 321-332. doi: 10.1007/s00438-011-0647-7

Yu, W., Wang, L., Zhao, R., Sheng, J., Zhang, S., Li, R., et al. (2019). Knockout of SIMAPK3 enhances tolerance to heat stress involving ROS homeostasis in tomato plants. BMC Plant Biol. 19, 1-13. doi: 10.1186/s12870-019-1939-z

Yu, X., Chen, G., Guo, X., Lu, Y., Zhang, J., Hu, J., et al. (2017). Silencing SIAGL6, a tomato AGAMOUS-LIKE6 lineage gene, generates fused sepal and green petal. Plant Cell Rep. 36, 959-969. doi: 10.1007/s00299-0172129-9

Yuste-Lisbona, F.J., Fernández-Lozano, A., Pineda, B., Bretones, S., OrtízAtienza, A., García-Sogo, B., et al. (2020). ENO regulates tomato fruit size through the floral meristem development network. PNAS. 117, 8187-8195. doi: 10.1073/pnas.1913688117

Zhang, T., Li, Z., Li, D., Li, C., Wei, D., Li, S., et al. (2020). Comparative effects of glycinebetaine on the thermotolerance in $\operatorname{codA}$ - and $B A D H$-transgenic tomato plants under high temperature stress. Plant Cell Rep. 39, 1525-1538. doi: 10.1007/s00299-020-02581-5

Zhang, Y., Mian, M., and Bouton, J. (2006). Recent molecular and genomic studies on stress tolerance of forage and turf grasses. Crop Sci. 46, 497-511. doi: 10.2135/cropsci2004.0572

Zhao, X., Muhammad, N., Zhao, Z., Yin, K., Liu, Z., Wang, L., et al. (2021). Molecular regulation of fruit size in horticultural plants: A review. Sci. Hortic. 288:110353. doi: 10.1016/j.scienta.2021.110353

Zhong, L., Zhou, W., Wang, H., Ding, S., Lu, Q., Wen, X., et al. (2013). Chloroplast small heat shock protein HSP21 interacts with plastid nucleoid protein pTAC5 and is essential for chloroplast development in Arabidopsis under heat stress. Plant Cell 25, 2925-2943. doi: 10.1105/tpc. 113.111229

Zhou, R., Kjaer, K., Rosenqvist, E., Yu, X., Wu, Z., and Ottosen, C.O. (2017). Physiological response to heat stress during seedling and anthesis stage in tomato genotypes differing in heat tolerance. J. Agron. Crop Sci. 203, 68-80. doi: 10.1111/jac.12166

Zhou, R., Kong, L., Yu, X., Ottosen, C.-O., Zhao, T., Jiang, F., et al. (2019). Oxidative damage and antioxidant mechanism in tomatoes responding to drought and heat stress. Acta Physiol. Plant. 41, 20. doi: 10.1007/s11738-019-2805-1

Zhou, R., Yu, X., Kjær, K.H., Rosenqvist, E., Ottosen, C.-O., and Wu, Z. (2015). Screening and validation of tomato genotypes under heat stress using Fv/Fm to reveal the physiological mechanism of heat tolerance. Environ. Exp. Bot. 118, 1-11. doi: 10.1016/j.envexpbot.2015.05.006

Zhu, J.-K. (2016). Abiotic stress signaling and responses in plants. Cell 167, 313-324. doi: 10.1016/j.cell.2016.08.029

Zinn, K.E., Tunc-Ozdemir, M., and Harper, J.F. (2010). Temperature stress and plant sexual reproduction: uncovering the weakest links. J. Exp. Bot. 61, 1959-1968. doi: 10.1093/jxb/erq053

Conflict of Interest: The authors declare that the research was conducted in the absence of any commercial or financial relationships that could be construed as a potential conflict of interest.

Publisher's Note: All claims expressed in this article are solely those of the authors and do not necessarily represent those of their affiliated organizations, or those of the publisher, the editors and the reviewers. Any product that may be evaluated in this article, or claim that may be made by its manufacturer, is not guaranteed or endorsed by the publisher.

Copyright (C) 2021 Hoshikawa, Pham, Ezura, Schafleitner and Nakashima. This is an open-access article distributed under the terms of the Creative Commons Attribution License (CC BY). The use, distribution or reproduction in other forums is permitted, provided the original author(s) and the copyright owner(s) are credited and that the original publication in this journal is cited, in accordance with accepted academic practice. No use, distribution or reproduction is permitted which does not comply with these terms. 